This item was submitted to Loughborough's Research Repository by the author.

Items in Figshare are protected by copyright, with all rights reserved, unless otherwise indicated.

\title{
Biomarkers to identify and isolate senescent cells.
}

PLEASE CITE THE PUBLISHED VERSION

http://dx.doi.org/10.1016/j.arr.2016.05.003

\section{PUBLISHER}

(c) Elsevier

VERSION

AM (Accepted Manuscript)

\section{PUBLISHER STATEMENT}

This work is made available according to the conditions of the Creative Commons Attribution-NonCommercialNoDerivatives 4.0 International (CC BY-NC-ND 4.0) licence. Full details of this licence are available at: https://creativecommons.org/licenses/by-nc-nd/4.0/

\section{LICENCE}

CC BY-NC-ND 4.0

\section{REPOSITORY RECORD}

Matjusaitis, Mantas, Greg Chin, Ethan Anders Sarnoski, and Alexandra Stolzing. 2019. "Biomarkers to Identify and Isolate Senescent Cells.". figshare. https://hdl.handle.net/2134/21676. 


\section{Accepted Manuscript}

Title: Biomarkers to identify and isolate senescent cells

Author: Mantas Matjusaitis Greg Chin Ethan Anders

Sarnoski Alexandra Stolzing

PII: $\quad$ S1568-1637(16)30079-4

DOI: $\quad$ http://dx.doi.org/doi:10.1016/j.arr.2016.05.003

Reference: $\quad$ ARR 670

To appear in: $\quad$ Ageing Research Reviews

Received date: $\quad$ 4-2-2016

Revised date: $\quad$ 4-5-2016

Accepted date: $\quad 11-5-2016$

Please cite this article as: Matjusaitis, Mantas, Chin, Greg, Sarnoski, Ethan Anders, Stolzing, Alexandra, Biomarkers to identify and isolate senescent cells. Ageing Research Reviews http://dx.doi.org/10.1016/j.arr.2016.05.003

This is a PDF file of an unedited manuscript that has been accepted for publication. As a service to our customers we are providing this early version of the manuscript. The manuscript will undergo copyediting, typesetting, and review of the resulting proof before it is published in its final form. Please note that during the production process errors may be discovered which could affect the content, and all legal disclaimers that apply to the journal pertain. 


\section{Biomarkers to identify and isolate senescent cells}

Mantas Matjusaitis ${ }^{1}$, Greg Chin, Ethan Anders Sarnoski ${ }^{2}$, Alexandra Stolzing ${ }^{3,4}$

${ }^{1}$ Scottish Centre for Regenerative Medicine, The University of Edinburgh, Edinburgh, England

${ }^{2}$ Department of Molecular, Cellular, and Developmental Biology, Yale University, New Haven, CT, USA

${ }^{3}$ Institute IZBI, University of Leipzig, Leipzig, Germany

${ }^{4}$ Loughborough University, Loughborough, England

Corresponding author: Alexandra Stolzing, PhD, Loughborough University, Wolfson School, Epinal Way, LE11 3TU, Loughborough, UK. +44-1509-227577

A.Stolzing@lboro.ac.uk; Stolzing@gmail.com 


\title{
Highlights
}

- There is no single biomarker which can robustly identify senescent cells.

- Widely used senescent cell biomarkers should be used in combination for accuracy.

- Technologies like tangential flow filtration can be used to isolate senescent cells.

- Other methods, like senolytic viruses, could be used to remove senescent cells.

\begin{abstract}
Aging is the main risk factor for many degenerative diseases and declining health. Senescent cells are part of the underlying mechanism for time-dependent tissue dysfunction. These cells can negatively affect neighbouring cells through an altered secretory phenotype: the senescence-associated secretory phenotype (SASP). The SASP induces senescence in healthy cells, promotes tumour formation and progression, and contributes to other age-related diseases such as atherosclerosis, immune-senescence and neurodegeneration. Removal of senescent cells was recently demonstrated to delay age-related degeneration and extend lifespan.
\end{abstract}

To better understand cell aging and to reap the benefits of senescent cell removal, it is necessary to have a reliable biomarker to identify these cells. Following an introduction to cellular senescence, we discuss several classes of biomarkers in the context of their utility in identifying and/or removing senescent cells from tissues. Although senescence can be induced by a variety of stimuli, senescent cells share some characteristics that enable their identification both in vitro and in vivo. Nevertheless, it may prove difficult to identify a single biomarker capable of distinguishing senescence in all cell types. Therefore, this will not be a comprehensive review of all senescence biomarkers but rather an outlook on technologies and markers that are most suitable to identify and isolate senescent cells.

Keywords: Aging, senescence, biomarkers, cell biology 


\section{Introduction}

\subsection{Aging and cellular senescence}

Our society is rapidly aging and the incidence of age-related diseases, such as Alzheimer's, diabetes and cancer is increasing (Christensen et al., 2009). If these trends continue, aging will become a major economic and social burden (Harper, 2014; Kankeu et al., 2013; Wimo et al., 2013). To avert this impending crisis, we must better understand why we age. Aging is a heterogenic process at both the organismal and cellular level. The number of contributing internal and external factors, such as epigenetic changes (Sinclair and Oberdoerffer, 2009) and the environment, make it difficult to categorize and prioritize the importance of each component. Such diversity has given rise to multiple theories regarding the root cause of aging (Harman, 1956; Park and Yeo, 2013; Wei et al., 2001), which sometimes contradict but more often complement one another. The variety of associated causes implies that aging is likely to be multifactorial in nature (Riess and Krüger, 1999; Sheikh et al., 2013).

One known aging factor is cellular senescence. Senescent cells accumulate with age in organisms, albeit at different rates in the various organs (Erusalimsky and Kurz, 2005; Herbig et al., 2006; Jeyapalan et al., 2007; Paradis et al., 2001). Originally, cellular senescence was defined as a loss of replicative capacity (Hayflick, 1965) caused by a progressive shortening of the tandem repeats protecting chromosome ends (telomeres). This eventually leads to chromosomal damage and replicative arrest (Campisi, 1997). Interestingly, cellular senescence can also be induced by stress (Toussaint et al., 2000) and oncogenes (Bartkova et al., 2006), demonstrating that cellular senescence is not only caused by exhaustion of replicative capacity as first thought. Such heterogeneity of cellular senescence, which we will briefly discuss in the next paragraph, has led a field to sometimes unnecessary ambiguity, leaving researchers to disagree what cellular senescence entails (Burton and Faragher, 2015). For the purposes of this review, we define cellular senescence as a permanent (under physiological conditions) cell cycle arrest that is a result of cellular stress or damage, including but not limited to abnormal activation of oncogenes, telomere shortening and macromolecule accumulation (De Cecco et al., 2011). With this description we deliberately exclude developmental senescence, quiescent cells, and post-mitotic cells.

\section{[Table 1]}




\subsection{Senescent cells in health and disease}

Cellular senescence is thought to have developed as a safeguard to prevent damaged cells from accumulating and either becoming cancerous or causing cancer (Figure 1). However, accumulation of senescent cells in tissues is detrimental to the animal (Herbig et al., 2006; Jeyapalan et al., 2007) as these non-functional cells directly and indirectly damage surrounding cells (Salama et al., 2014). Examples of such damage include occupying niches required by competent cells to function (Lynch, 2004), secreting transforming, inflammatory and otherwise damaging components of the SASP (Campisi and d'Adda di Fagagna, 2007; Coppé et al., 2010, 2008), promoting tumour formation (Leikam et al., 2015; Zacarias-Fluck et al., 2015) and contributing to various age-related diseases such as atherosclerosis (Irvine et al., 2014; Wang and Bennett, 2012).

While long-term accumulation of senescent cells is harmful to the organism, short-term senescence events prevent cancer (Kuilman et al., 2008), guide development (Muñoz-Espín et al., 2013) and improve tissue repair and wound healing (Demaria et al., 2014; Rodier and Campisi, 2011). One proposed mechanism to negate the long-term detrimental effects of senescent cells, while retaining their short-term beneficial functions, is to periodically purge them from the body. Regular elimination of p16-positive senescent cells from functionally wild-type mice slows time-dependent functional decline and extends median lifespan $\sim 30 \%$ (Baker et al., 2016, 2011). Moreover, recent studies have demonstrated clearance of senescent cells from wild-type mice using small molecules which target the BCL-2 protein family (Chang et al., 2016; Zhu et al., 2015), lending credence to this approach as a therapeutic strategy. However, no method currently exists to accomplish this in humans, in large part because senescent cells cannot yet be reliably identified in living tissue. In the following sections, we will discuss biomarkers and their utility in identifying or eliminating senescent cells in a living organism.

\subsection{Characteristics of useful biomarkers}

A biomarker is a biological signature of a condition which enables one to evaluate if the biological system (organism, cell, etc.) possesses that condition or not. Many molecules, such as proteins, nucleic acids, and lipids, can be used as a biomarker. They can be found within the cell, in the adjacent extracellular area, or even systemically in the circulatory system. Importantly, no single marker currently provides an accurate representation of cellular 
senescence.

A useful biomarker must display several important features. First, it should be robustly associated with the condition. Although it is likely that (i) context, such as cell type, will be relevant and that (ii) it may not identify all cases of cellular senescence, it is crucial that the presence of the marker strongly correlates with a specific condition. Second, it is essential to know the threshold at which a marker becomes representative of the specific feature. Most proteins are expressed at basal levels in many cells, and simple evaluation of the presence or absence of the protein is not informative. For discrimination purposes, it is imperative to identify a clear threshold value which defines the cellular status. Finally, to be practical, a marker must be quantifiable using current technologies. Even a comprehensive understanding of a marker is not practically helpful unless we are able to monitor its levels or purify cells positive for it.

In this review, we will emphasize markers of cellular senescence that would be practical to assay. Only single-cell markers of senescence will be discussed. Detailed reviews on systemic aging markers have been published previously (Falandry et al., 2013; Pallis et al., 2014).

\subsection{The challenge and benefits of finding robust cellular senescence markers}

While cellular senescence has been linked to a number of predictable phenotypic traits and representative biomarkers (Table 1), senescent cells are still a heterogeneous population, and this fact significantly complicates a search for a robust senescence biomarker. Senescent cells arising from different stimuli exhibit measurably distinct proteomes (Aan et al., 2013; Dierick et al., 2002; G. J. Aan, 2011). Moreover, gene expression profiles of senescent cells are cell type-specific (Schnabl et al., 2003). Considering recent breakthroughs in our understanding of a need for personalized medicine, it is likely that variation will be seen not only between different senescent cell types but also between individuals. Importantly, potential reversibility of senescent cells has to be taken into account when evaluating what is and what is not cellular senescence. Although the main consensus in the field is to grant senescence a permanent and irreversible status, a number of studies have shown that cell cycle inhibition can be reversed in human senescent fibroblasts by inhibition of p53 and/or p16, two key pathways used to established cellular senescence (Beauséjour et al., 2003; Ide et al., 1983). More recently, it has been shown that inhibition of $\mathrm{p} 38 \alpha / \beta$ MAPK lowers $\mathrm{p} 16$ 
levels and restores replicative capacity of aged mouse muscle stem cells (Cosgrove et al., 2014). Unfortunately, these studies did not look into other senescence marker in their models. Therefore, it is still not clear if these aged cells are only forced into the cell cycle from p16dependant growth arrest or if is it is a complete or partial reversal of cellular senescence. Interestingly, cellular senescence can be prevented by activating autophagy, either with rapamycin treatment or Atg7 overexpression, in aged satellite mouse and human muscle cells. However, it is not clear from this data if cellular senescence can be reversed (García-Prat et al., 2016). Even if senescence could not be reversed, it is clear that a large senescence biomarkers can be affected by defined molecules and conditions, which is an important consideration when looking for and validating such markers.

As cancer research has demonstrated, having robust, practical markers can enhance the research field in many ways (Henry and Hayes, 2012; Pallis et al., 2014). A reliable readout that identifies senescent cells would facilitate high-throughput screens as well as allow quantification of aging in various animal models. Most importantly, therapeutic techniques would benefit from robust markers to enable removal of senescent cells from tissues (such as blood filtering, Figure 3), stem cell preparations from aged autologous donors (Melk et al., 2009) and identification of replicative exhaustion in stem cell expansions. One example of how such markers could be used is a strategy using selectively-lytic viruses, which are already used in oncology (Elsedawy and Russell, 2013). These are genetically modified viruses which replicate, lyse and kill cells in the presence (or absence) of specific gene products and, therefore, allow selective targeting. This strategy has successfully reached regulatory approvals in China and the USA for cancer treatment (Garber, 2006; Pol et al., 2015). Theoretically, such a therapy could be applied to senescent cell removal as well.

Currently, due to the heterogeneity of cellular senescence and ambiguity of the term (Table 1), there is no known universal biomarker which can selectively but broadly identify senescent cells in different tissues and extracellular environments. In this review, we will discuss a number of studies which have made significant strides towards the identification and validation of cellular senescence biomarkers.

\section{Surface markers \& secretion profile}

Surface and external factors are ideal biomarkers, as they can be detected without intracellular delivery of a probe and without harming the cell. Multiple surface markers have 
been associated with senescent cells, some more robust than others. Three major groups of such molecules will be covered: secreted factors, plasma membrane (PM)-associated proteins and PM lipid composition.

\subsection{Secreted biomarkers}

Secreted factors have excellent potential as biomarkers because detection methods can be contact-free, allowing measurement without disturbing the cells. However, secreted markers are intractable to cell isolation until technology is available which can detect the secretion of single-cells during the selection process.

The senescence-associated secretory phenotype (SASP) has been observed in many different cell types (Acosta et al. 2008; Campisi et al. 2011). One study has defined many of the factors which are secreted by aged human fibroblasts and epithelial cells (Campisi et al., 2008). This list of factors includes but is not limited to inflammatory mediators (such as IL-6 and MIP-3a), growth factors (such as HGF, GRO, and IGF-binding proteins), detached cell surface molecules, and extracellular matrix components. Multiple studies have validated SASP and its related factors as robust markers of senescence, which makes them very promising candidates (Acosta et al., 2013; Sandeman et al., 2001).

Interestingly, another secretory profile of senescent cells recently has been identified. The telomere-associated secretory phenotype (TASP) has been associated with replicative senescence (Braig et al., 2014; Jiang et al., 2008). It is not clear if this phenotype should be classified as separate from the SASP phenotype. However, it does provide some new and unique markers to consider. These include cathelin-related antimicrobial peptide (CRAMP), chitinase, stathmin, and EF-1 $\alpha$. Interestingly, one study has shown that CRAMP and chitinase levels highly correlate not only with replicative senescence but also with human aging in general (Lu et al., 2014).

These secretory profiles are useful tools for evaluating general tissue or cell culture senescence. Some recent publications covered various ways of detecting such phenotypes. One such method is the SASP-responsive alkaline phosphatase (SASP-RAP) assay, where activity of secreted alkaline phosphatase is measured by a commercial chemiluminescence kit. SASP-RAP reliably detected senescence in rat renal tubular epithelial cells and mouse embryonic fibroblasts treated with etoposide, a DNA-damaging agent (Gu and Kitamura, 2012). ELISA protocols have also been developed for an array of SASP components, 
including IL-6 (Rodier, 2013). Moreover, it also may be possible to detect SASP by monitoring the known effects on surrounding cells. For example, senescent fibroblasts affect epithelial cell proliferation which can, in turn, be quantified as an indirect marker (Parrinello et al., 2005).

Nevertheless, it is important to understand that there are some major limitations inherent to secretory markers. Firstly, the SASP may vary between cell types and between different stages of senescence (Coppé et al., 2010; Maciel-Barón et al., 2016; Rodier et al., 2009). Secondly, current technology does not permit the rapid, high-throughput analysis of singlecell secretory phenotypes necessary to isolate a population on this basis. Although this technological gap currently prevents the use of a secreted marker for selective cell removal, secreted biomarkers are still applicable for general identification of senescent cells and potentially for diagnostic tests aiming to quantify the burden of cellular senescence in an individual.

\subsection{Plasma membrane-associated proteins}

Another set of surface structures which could be used for identifying and isolating senescent cells are plasma membrane-associated proteins, such as receptors and glycoproteins. As these structures are the main means of interaction between extracellular and intracellular compartments, their composition and functionality is essential for cell homeostasis.

Several independent research groups have shown that plasma membrane (PM) glycoprotein composition is altered in aged cells (Poot et al., 1986; Wu et al., 2009). Glycoproteins are important components and play a role in many functions, including signalling in immune system and hormone responses (Ervasti, 2000; Li et al., 2010). There is a wide range of possible glycoprotein variants, and specific glycoprotein compositions have been linked to a senescence profile. For example, senescent human fibroblasts exhibit higher levels of concanavalin A, fucose, and glucosamine (Blondal et al., 1985).

Expression changes in the concentration of PM-associated proteins could also be used as a senescence biomarker. Althubiti and colleagues have identified 107 PM-associated proteins upregulated in a human bladder cancer cell line induced to senesce by ectopic expression of p16 and p21. Ten of these upregulation events were validated by western blots and immunocytochemistry (Althubiti et al., 2014), while several additional candidates like 
ICAM-1 had previously been reported to increase in senescent cells (Schnabl et al., 2003).

Several standard methods exist to measure expression changes in PM proteins, including immunocytochemistry (Obradovic and Jurisic, 2012) and techniques utilizing other proteinspecific probes (Liu et al., 2005). Changes in the expression of PM proteins can also be detected with transductionally targeted recombinant viruses, which are able to enter only those cells with the appropriate ligand exposed on the PM. This has been accomplished in cancer cells already and readers are referred to an excellent review by Everts and Curiel for more information (Everts and Curiel, 2004). A similar strategy could be used to target senescent cells. The specific targeting of senescent cells holds promise both as a senescent assay and as a potential therapeutic. Transductionally targeted viruses could be engineered to selectively kill senescent cells or to carry a fluorescence reporter gene for identification (Perez et al., 2013) (Figure 4).

\subsection{Plasma membrane lipid composition}

The third type of marker which can be used to identify and isolate senescence cells is linked to PM lipid composition (Sud et al., 2007). Although PM lipid-based senescence biomarkers are less established and harder to detect compared to other surface signatures, some promising candidates and techniques have emerged which hold great potential for senescent cell identification and isolation.

Membrane lipid composition and membrane biophysical properties change in senescent cells. Plasma membranes, due to altered lipid composition, become more rigid with age (Fulop et al., 2012a; Momchilova et al., 2014). Moreover, senescent cells increase in size compared to non-senescent analogues (Kim et al., 2015; Rodier and Campisi, 2011). This modifies many essential functions within the cell, such as diffusion, cell size, membrane fusion, chemical and electrical processes, cell elasticity and membrane stiffness (Pontes et al., 2013). Such cellular mechanics have already been used as biomarkers to identify cancer cells, malaria-infected cells and primary cells (Darling et al., 2008; Suresh et al., 2005).

A number of technologies have emerged to detect PM biomechanical and lipid composition differences between cells. For example, tangential flow filtration (Cai et al., 2015) discriminates between cells based on membrane stiffness. Such a method has been successfully used to separate differentiated cells from pluripotent ones (Willoughby et al., 2016). Moreover, a technology which selects cells based on cell mechanics has been used to sort red blood cells based on shape and deformation (Beech et al., 2012), which make this 
sub-group of senescence markers even more viable.

Another structure which could be used as a marker is a lipid raft (LR). LRs are small, dynamic structures in the plasma membrane that are high in cholesterol and low in unsaturated phospholipids (Brown, 2006). These structures recruit signalling components to the plasma membrane (Kabouridis, 2006). It has been shown that $\mathrm{T}$ cells from young subjects have a different LR distribution and functionality compared to T cells from older individuals, although it is still not clear if these changes are linked to senescent or aged cells in general (Fulop et al., 2012b; Larbi et al., 2006, 2004).

LR dispersal can be measured using CTxB fluorescent molecules that bind to GM1 gangliosides, which are LR markers (Holleran, 2003). Moreover, it is possible to use specific fluorescent LR probes, such that quantifying the number of probes bound could be used as a means of identifying senescent cells (Mikhalyov and Samsonov, 2011). For a full analysis of the most current methods for studying membrane microdomains (including LRs and the signalosome) in intact cells, readers are advised to refer to Lagerholm's review (Lagerholm et al., 2005).

In summary, membrane lipid composition and its effects on cell biophysical properties represent a promising line of exploration for developing reliable, quantitative senescence markers.

\section{Intracellular senescence biomarkers}

Many intrinsic changes have been observed in senescent cells. While currently known intrinsic changes are more discrete and better defined compared to surface ones, they are harder to measure in live tissue. Three major groups of potential biomarkers will be covered: DNA-related markers, protective mechanism or damage signatures, and cell cycle genes.

\subsection{DNA-related senescence biomarkers}

It is still not clear if mutations significantly contribute to aging, but the cumulative number of mutations and the rate at which they accumulate increases with age in model organisms and senescent cells (Kennedy et al., 2012; Sedelnikova et al., 2004). Moreover, accelerated-aging diseases, such as Werner and Cockayne Syndromes, are linked to 
malfunctioning DNA repair mechanisms (Rossi et al., 2010). Such findings make it tempting to speculate that DNA quality, metabolism, and maintenance are key mechanisms in the biology of aging. That being said, most of the changes which will be discussed are not exclusive to senescent cells and therefore use as a sole marker would yield a significant proportion of false positives.

Various markers for DNA damage, such as $\gamma \mathrm{H} 2 \mathrm{AX}$, 53BPI foci, Rad17, ATM and MDC1, are commonly used as conditional markers of cellular senescence (Lawless et al. 2010; Wang et al. 2009; Sharma et al. 2012). $\gamma \mathrm{H} 2 \mathrm{AX}$ immunocytochemistry has been shown to effectively mark senescent fibroblasts (von Zglinicki et al., 2005). Although these markers are well established, they do not represent cellular senescence directly. $\gamma \mathrm{H} 2 \mathrm{AX}$ is a marker for DNA double-strand breaks (DSBs), which is neither necessary for nor exclusive to cellular senescence (Chapman et al., 2012). Similar limitations exist for other DNA damage related biomarkers (Awasthi et al., 2015).

DNA synthesis markers can also serve as negative indicators for cellular senescence. DNA synthesis rate can be analyzed in 5-bromo-2'deoxyuridine (BrdU) or 5-ethynyl-2'dexyuridine (EdU) incorporation assays (Gratzner, 1982; Salic and Mitchison, 2008). Only cells that are undergoing DNA synthesis are able to incorporate transiently available BrdU or EdU nucleosides. The incorporation rate of such synthetic nucleosides is low in senescent cells, which suggests that DNA replication is near-absent (Voutetakis et al., 2015). Another assay for cell proliferation is based on immunostaining for marker Ki-67 (Urruticoechea et al., 2005). However, assays based on DNA synthesis would also identify other nonreplicative cells, such as quiescent cells and post-mitotic cells, which make such markers suboptimal if used alone.

Telomere length can also be used as a biomarker for replicative senescence (Mather et al. 2011; Zietzer \& Hillmeister 2014; Bekaert et al. 2005.). However, the shortening of telomeres associated with replicative senescence has yet to be translated into a common assay. There are several ways to measure telomere status in the cell. Measuring telomere length by quantitative PCR is one way (Cawthon 2002). Moreover, protocols have been designed which allow measurement of absolute telomere length (O'Callaghan and Fenech, 2011) or telomere length of a single-cell (Wang et al., 2013). Unfortunately, these PCR-based approaches to telomere measurement require destruction of the cell. Fluorescence in situ hybridization (FISH) can be used to visualize the length of telomeres in fixed but intact cells (O’Sullivan et al., 2005; Ourliac-Garnier and Londoño-Vallejo, 2011), which retains 
information such as subcellular localization. Moreover, FISH can be combined with flow cytometry to provide information on telomere length in thousands of cells (Baerlocher et al., 2006; Hultdin et al., 1998).

In addition to the direct measurement of telomere length, another potential aging marker is telomere dysfunction-induced foci (TIF) (Brugat et al., 2010; Sahin et al., 2011). TIF is a term used to describe telomeres which accumulated various DNA damage factors, such as $\gamma \mathrm{H} 2 \mathrm{AX}$, ATM and Mre11 (Badie et al., 2010; Takai et al., 2003). TIF has been shown to increase in baboon fibroblasts that have undergone replicative senescence (Jeyapalan et al., 2007) and also has an effect on the metabolic status of the cell (Sahin et al., 2011). Therefore, it may be possible to identify senescent cells by immunostaining for these factors at telomeres.

Epigenetic changes, including senescence-associated heterochromatic foci (SAHF), can also be used as biomarkers for cellular senescence. Epigenetics largely determine cellstate differences in a genetically identical population, such as within an organism (Sinclair and Oberdoerffer, 2009). Although epigenetic markers vary depending on the environmental context and type of cell (Kosar et al., 2011), epigenetic profiles have been defined for various conditions, including cancer (Dumitrescu, 2012; Mäbert et al., 2014) and aged human cells (Horvath, 2013). A specific heterochromatin profile has been linked to cellular senescence (Kosar et al., 2011; Narita et al., 2003). SAHFs, domains of heterochromatin that contribute to silencing of proliferative genes in senescent cells (Narita, 2007), can be detected by multiple methods, including DAPI staining and immunocytochemistry against SAHF components, such as HP1 (Aird and Zhang, 2013). Another novel assay, called chromatin in vivo assay (CiA), has the potential to be used in high-throughput screening for heterochromatin alterations (Jones, 2012). It may be possible to adapt it to report SAHFs.

In summary, DNA-related signatures are some of the most prominent cellular senescence biomarkers. In addition to the fact that one or more of these markers can robustly be found in most senescent cells, the broad availability of methods for their detection makes this biomarker group extremely potent. Further discussion of how they can be used in combination with other markers to increase specificity will be discussed later in the review.

\subsection{Protective mechanism and damage markers}

Aging is closely linked to loss of damage repair and/or stress response capabilities, which results in the accumulation of various toxic by-products and other macromolecules (Chen et 
al., 2007; Hipkiss, 2006). As a result, enzymatic by-products and activities of various lysosomal and proteosomal enzymes, which are responsible for aggregate clearance, are often altered in aged cells (García-Prat et al., 2016). The ability to detect such changes would help to identify and possibly isolate senescence cells.

Perhaps the most frequently used biomarker for senescent cells is increased activity of $\beta$ galactosidase ( $\beta$-gal) (Bassaneze et al., 2008; Dimri et al., 1995), which reflects increased lysosomal mass (Kurz et al., 2000). Several techniques exist for $\beta$-gal detection, including fluorescence-based and cytochemical methods (Debacq-Chainiaux et al., 2009). However, $\beta$ gal activity also increases in quiescence and in response to various forms of stress (Yang and $\mathrm{Hu}, 2005)$. Thus, $\beta$-gal as a sole marker may often yield false-positives and is best used in combination with other markers. A similar marker, $\alpha$-fucosidase, has recently been reported (Hildebrand et al., 2013). While this marker boasts similar ease of detection, it remains uncertain if it is equally, more, or less specific for senescence than $\beta$-gal.

Proteasomes, protein complexes responsible for degrading unneeded or damaged proteins, may also act as useful biomarkers for senescence. For example, $26 \mathrm{~S}$ proteasome activity is reduced in human primary senescent fibroblasts (Chondrogianni et al., 2003; Reinheckel et al., 1998; Torres and Perez, 2008), and 26 S proteasome activity has recently been measured using fluorogenic peptide substrates (Georgila et al., 2014). While this assay has not yet been applied to senescent cells, it may serve as a secondary marker in conjunction with other indicators of cellular senescence.

Reactive oxygen species (ROS) can also be used for senescent cell detection. ROS are involved in oxidative stress, signalling and differentiation processes. ROS increase with age and correlate with many age-related cellular changes (Liochev, 2013). Furthermore, elements associated with protection against oxidative stress (Cox2, SOD, Mn and other antioxidants) often show reduced functionality in aged organisms (Espinoza et al., 2008; Paul et al., 2007).

However, oxidative stress, like many other markers mentioned in this review, is only an indirect marker of senescence. It is not necessary for cells to have high ROS activity to become senescent. Furthermore, a low level of ROS, is not only useful but essential for normal cellular functions (Liochev, 2013). Conversely, high ROS levels are not always associated with senescence as they are sometimes linked to differentiation (Paul et al., 2014). This may make interpretation of results problematic if clear thresholds (and their deviation depending on environment) are not determined. Various assays, including commercially available kits, exist to measure oxidative stress markers and levels of intracellular ROS 
(Starkov, 2010; Fan and Li, 2014). Most of these techniques rely on fluorescence detection with either flow cytometry/fluorescence microscopy or chemiluminescence.

In summary, markers of cellular damage and protection mechanisms, such as ROS and $\beta$ Gal, are well-known signatures of cellular senescence. While not exclusive to cellular senescence, these relatively easy-to-assay markers are frequently employed as companion diagnostics.

\subsection{Cell cycle genes}

Arrest of cell proliferation is a hallmark of a senescent cell, which means that genes responsible for such regulation can potentially be used as markers to identify which cells are senescent.

During growth arrest, various cell cycle inhibitors such as p53 and p21 are activated (Campisi, 2005). p21 waf is a cyclin-dependant kinase (CDK) inhibitor which acts by mediating $\mathrm{pRB}$ dephosphorylation. Its overexpression promotes cellular senescence as shown by $\beta$-gal activity, telomere length and DNA damage monitoring (Huang et al., 2004). Moreover, if $\mathrm{p} 21^{\mathrm{waf}}$ is down-regulated in senescent cells, replicative capacity is restored (Schnabl et al., 2003).

Another molecular alteration that is specific to senescent cells is the phosphorylation (and activation) of p53 at serine 15 . This phosphorylation has been observed in normal human fibroblasts that have undergone replicative senescence (Webley et al., 2000), oncogeneinduced senescence (Ferbeyre et al., 2000), and other forms of senescence (Ghosh et al., 2008). p53 and the related tumor suppressor $\mathrm{p} 16^{\mathrm{INK} 4 \mathrm{a}}$ are relatively robust markers of senescence as their expression is required to induce the characteristic permanent cell cycle arrest (Campisi and d'Adda di Fagagna, 2007; Krishnamurthy et al., 2004; Vandenberk et al., 2011). However, these genes are not absolute markers of cellular senescence. For example, p53 is also responsible for apoptotic programmed cell death (Amaral et al., 2010). An assay relying solely on p53 levels, therefore, would not be able to discriminate senescent cells from those undergoing apoptosis. Furthermore, mutations may shift p53 activity patterns (Muller and Vousden, 2013). In such cases, p53 mutations, although tumorigenic, may not be linked to cellular senescence. Moreover, a reversible growth arrest state, known as quiescence, also depends on the aforementioned cell cycle inhibitors (Li and Bhatia, 2011). Although such context specificity would make these biomarkers unreliable if used alone, their use in a 
combinatorial strategy could be very potent.

\section{Summary of most promising senescence biomarkers and combinatory approach}

\subsection{Synopsis of the most practical markers for identification and isolation of senescent cells.}

Some of the cellular senescence biomarkers are more practically viable either because of their relative robustness to accurately select senescent cells or existing technologies for their detection. In the following paragraph, we offer our opinion of the most promising senescence biomarkers.

Firstly, markers for cell cycle genes (p16, p21, p53, Rb) and DNA synthesis (BrdU incorporation) provide a robust way to distinguish dividing cells from non-dividing cells. Considering that cell cycle arrest is a hallmark of cellular senescence, such markers carry great potential. That being said, if used alone, these assays would also identify non-senescent, non-proliferative cells, such as post-mitotic neurons or quiescent stem cells. Other senescence markers should be used in combination to alleviate such off-target effects.

Secondly, due to the non-proliferative and dysfunctional nature of senescent cells, an accumulation of various intracellular junk and a stressed cellular repair mechanism are often observed. This makes a number of pathways a potential source for biomarkers, the most prominent example being $\beta$-gal activity in lysosomes. With a number of assays now available to detect such changes, this category of biomarkers may offer several strong candidates for diagnostic assays.

Thirdly, considering recent developments in the ability to quantify cell biomechanical properties (Beech et al., 2012; Darling et al., 2008; Suresh, 2007) and plasma membrane elasticity alterations observed in senescent cells, new technologies could arise that would enable senescent cell identification and isolation. Similar approaches, based on tangential flow filtration, for example, have been used successfully to separate pluripotent cells from heterogeneous populations (Willoughby et al., 2016).

Lastly, senescent cell surface components, such as ICAM-1 and NOTCH3, are very attractive biomarkers due to possibility of screening live cells without damaging them. Moreover, a number of techniques are available to achieve such aims, including immunocytochemistry, transductionally targeted viruses, FACS or magnetic cell sorting. Recent studies have also identified a large number of novel surface markers, which potentially may join the list of commonly used signatures for senescence (Althubiti et al., 


\subsection{Using combinations of markers for a more robust and specific assay}

To achieve the highest possible specificity of an assay, a combination of the most prominent markers should be used. To date, it is common best practice in the cellular senescence research field to use a panel of markers to validate that cells are senescent (Acosta et al., 2013; Guo et al., 2009). p53, p16, $\beta$-gal and telomere length remain the most commonly used markers and their combination should accurately pinpoint senescent cells. Although essential, a four-piece requirement for identification and isolation is practically challenging and cost- and time-ineffective. We propose that a synthetic reporter (or lytic) virus could potentially be used as a single system with combinatorial potential.

Similar strategies have been successfully used in the past for oncolytic viruses where input from multiple sources (genes, receptors etc.) was required for the function of the virus (Barker et al., 2003; Larson et al., 2015; Lee et al., 2010; Singh et al., 2012). For example, one study constructed an adenovirus in which gene E1a was under the control of the hTERT (human telomerase reverse transcriptase) promoter while the viral gene E1b was under the control of the HRE (hypoxia response element) promoter (Wang et al., 2008). Such a system allowed viral replication only in hypoxic cells with active telomerase, which are very common signatures for cancer cells. Although this particular example utilized two different promoters, much more elaborate bio-sensor circuits could be built to allow even greater specificity. Theoretically, most transcriptional signatures can be targeted with these viruses by genetically modifying viral promoters. Moreover, viral coat engineering allows specifying to which surface markers a viral particle can bind and consequently infect a target cell (Verheije and Rottier, 2012).

\section{Outlook}

In this review, we have covered a number of biological signatures, outlining their advantages and disadvantages as cellular senescence biomarkers. Some of them are widely accepted to mark an aspect of aging (telomeres, ROS etc.), while other molecules, such as lipid rafts, still require further validation as a practical marker.

One of the major limitations of all these markers is the fact that the change is only 
relative. For example, ROS is always present in the cells and small amounts are essential for intrinsic signalling. Although an increase in ROS levels is considered to be a marker of oxidative stress and possibly cellular senescence, at what point does the difference become a biomarker? Furthermore, can we robustly classify a measurement that can be considered a definitive indicator of senescence in all circumstances? These questions remain to be answered. Another important aspect is use of biomarker combinations. None of the markers can accurately and robustly detect senescent cells in all given instances. This is why it may be useful to use a combination of markers. Such combinations of complementing markers, such as the ones we have suggested, would offer a diagnostic with better accuracy and robustness.

Although senescent cell markers are widely used in basic research, such signatures may also be useful in the clinic as well. Removal of senescent cells has been shown to have a positive effect on murine health. With increasing knowledge in immuno- and viro-therapies, new opportunities may arise to use senescence biomarkers in senescent cell removal procedures for therapeutic benefit.

\section{Acknowledgments}

The work presented in this paper was made possible by funding from the German Federal Ministry of Education and Research (BMBF1315883). We thank Claudia Garcia-Diaz for helpful comments and advice on the figures.

\section{References}

Aan, G.J., Hairi, H.A., Makpol, S., Rahman, M.A., Karsani, S.A., 2013. Differences in protein changes between stress-induced premature senescence and replicative senescence states. Electrophoresis 34, 2209-17. doi:10.1002/elps.201300086

Acosta, J.C., Banito, A., Wuestefeld, T., Georgilis, A., Janich, P., Morton, J.P., Athineos, D., Kang, T.-W., Lasitschka, F., Andrulis, M., Pascual, G., Morris, K.J., Khan, S., Jin, H., Dharmalingam, G., Snijders, A.P., Carroll, T., Capper, D., Pritchard, C., Inman, G.J., Longerich, T., Sansom, O.J., Benitah, S.A., Zender, L., Gil, J., 2013. A complex secretory program orchestrated by the inflammasome controls paracrine senescence. Nat. Cell Biol. 15, 978-90. doi:10.1038/ncb2784 
Acosta, J.C., O’Loghlen, A., Banito, A., Guijarro, M. V, Augert, A., Raguz, S., Fumagalli, M., Da Costa, M., Brown, C., Popov, N., Takatsu, Y., Melamed, J., d’Adda di Fagagna, F., Bernard, D., Hernando, E., Gil, J., 2008. Chemokine signaling via the CXCR2 receptor reinforces senescence. Cell 133, 1006-18. doi:10.1016/j.cell.2008.03.038

Aird, K.M., Zhang, R., 2013. Detection of senescence-associated heterochromatin foci (SAHF). Methods Mol. Biol. 965, 185-96. doi:10.1007/978-1-62703-239-1_12

Althubiti, M., Lezina, L., Carrera, S., Jukes-Jones, R., Giblett, S.M., Antonov, A., Barlev, N., Saldanha, G.S., Pritchard, C.A., Cain, K., Macip, S., 2014. Characterization of novel markers of senescence and their prognostic potential in cancer. Cell Death Dis. 5, e1528. doi:10.1038/cddis.2014.489

Amaral, J.D., Xavier, J.M., Steer, C.J., Rodrigues, C.M., 2010. The role of p53 in apoptosis. Discov. Med. 9, 145-52.

Awasthi, P., Foiani, M., Kumar, A., 2015. ATM and ATR signaling at a glance. J. Cell Sci. 128, 4255-62. doi:10.1242/jcs. 169730

Badie, S., Escandell, J.M., Bouwman, P., Carlos, A.R., Thanasoula, M., Gallardo, M.M., Suram, A., Jaco, I., Benitez, J., Herbig, U., Blasco, M.A., Jonkers, J., Tarsounas, M., 2010. BRCA2 acts as a RAD51 loader to facilitate telomere replication and capping. Nat. Struct. Mol. Biol. 17, 1461-9. doi:10.1038/nsmb.1943

Baerlocher, G.M., Vulto, I., de Jong, G., Lansdorp, P.M., 2006. Flow cytometry and FISH to measure the average length of telomeres (flow FISH). Nat. Protoc. 1, 2365-76. doi:10.1038/nprot.2006.263

Baker, D.J., Childs, B.G., Durik, M., Wijers, M.E., Sieben, C.J., Zhong, J., Saltness, R.A., Jeganathan, K.B., Casaclang Verzosa, G., Pezeshki, A., Khazaie, K., Miller, J.D., Van Deursen, J.M., 2016. Naturally occurring p16 Ink4a -positive cells shorten healthy lifespan. Nature 530, 184-189. doi:10.1038/nature16932

Barker, S.D., Dmitriev, I.P., Nettelbeck, D.M., Liu, B., Rivera, A.A., Alvarez, R.D., Curiel, D.T., Hemminki, A., 2003. Combined transcriptional and transductional targeting improves the specificity and efficacy of adenoviral gene delivery to ovarian carcinoma. Gene Ther. 10, 1198-204. doi:10.1038/sj.gt.3301974 
Bartkova, J., Rezaei, N., Liontos, M., Karakaidos, P., Kletsas, D., Issaeva, N., Vassiliou, L.V.F., Kolettas, E., Niforou, K., Zoumpourlis, V.C., Takaoka, M., Nakagawa, H., Tort, F., Fugger, K., Johansson, F., Sehested, M., Andersen, C.L., Dyrskjot, L., Ørntoft, T., Lukas, J., Kittas, C., Helleday, T., Halazonetis, T.D., Bartek, J., Gorgoulis, V.G., 2006. Oncogene-induced senescence is part of the tumorigenesis barrier imposed by DNA damage checkpoints. Nature 444, 633-7. doi:10.1038/nature05268

Bassaneze, V., Miyakawa, A.A., Krieger, J.E., 2008. A quantitative chemiluminescent method for studying replicative and stress-induced premature senescence in cell cultures. Anal. Biochem. 372, 198-203. doi:10.1016/j.ab.2007.08.016

Beauséjour, C.M., Krtolica, A., Galimi, F., Narita, M., Lowe, S.W., Yaswen, P., Campisi, J., 2003. Reversal of human cellular senescence: Roles of the p53 and p16 pathways. EMBO J. 22, 4212-4222. doi:10.1093/emboj/cdg417

Beech, J.P., Holm, S.H., Adolfsson, K., Tegenfeldt, J.O., 2012. Sorting cells by size, shape and deformability. Lab Chip 12, 1048-51. doi:10.1039/c2lc21083e

Bekaert, S., De Meyer, T., Van Oostveldt, P., 2005. Telomere attrition as ageing biomarker. Anticancer Res. 25, 3011-21.

Biran, A., Krizhanovsky, V., 2015. Senescent cells talk frankly with their neighbors. Cell Cycle 14, 2181-2. doi:10.1080/15384101.2015.1056608

Blondal, J.A., Dick, J.E., Wright, J.A., 1985. Membrane glycoprotein changes during the senescence of normal human diploid fibroblasts in culture. Mech. Ageing Dev. 30, $273-$ 83.

Borton, M., Docherty, J.R., 1989. The effects of ageing on neuronal uptake of noradrenaline in the rat. Naunyn. Schmiedebergs. Arch. Pharmacol. 340, 139-43.

Braig, M., Pällmann, N., Preukschas, M., Steinemann, D., Hofmann, W., Gompf, A., Streichert, T., Braunschweig, T., Copland, M., Rudolph, K.L., Bokemeyer, C., Koschmieder, S., Schuppert, A., Balabanov, S., Brümmendorf, T.H., 2014. A “telomereassociated secretory phenotype" cooperates with BCR-ABL to drive malignant proliferation of leukemic cells. Leukemia. doi:10.1038/leu.2014.95

Brown, D.A., 2006. Lipid rafts, detergent-resistant membranes, and raft targeting signals. 
Physiology (Bethesda). 21, 430-9. doi:10.1152/physiol.00032.2006

Brugat, T., Nguyen-Khac, F., Grelier, A., Merle-Béral, H., Delic, J., 2010. Telomere dysfunction-induced foci arise with the onset of telomeric deletions and complex chromosomal aberrations in resistant chronic lymphocytic leukemia cells. Blood 116, 239-49. doi:10.1182/blood-2009-12-257618

Burton, D.G.A., Faragher, R.G.A., 2015. Cellular senescence: from growth arrest to immunogenic conversion. Age (Omaha). 37, 1-19. doi:10.1007/s11357-015-9764-2

Cai, L., Yang, Y., Jiao, N., Zhang, R., 2015. Evaluation of Tangential Flow Filtration for the Concentration and Separation of Bacteria and Viruses in Contrasting Marine Environments. PLoS One 10, e0136741. doi:10.1371/journal.pone.0136741

Campisi, J., 2005. Senescent cells, tumor suppression, and organismal aging: good citizens, bad neighbors. Cell 120, 513-22. doi:10.1016/j.cell.2005.02.003

Campisi, J., 1997. The biology of replicative senescence. Eur. J. Cancer 33, 703-9. doi:10.1016/S0959-8049(96)00058-5

Campisi, J., Andersen, J.K., Kapahi, P., Melov, S., 2011. Cellular senescence: a link between cancer and age-related degenerative disease? Semin. Cancer Biol. 21, 354-9. doi:10.1016/j.semcancer.2011.09.001

Campisi, J., d'Adda di Fagagna, F., 2007. Cellular senescence: when bad things happen to good cells. Nat. Rev. Mol. Cell Biol. 8, 729-40. doi:10.1038/nrm2233

Campisi, J., Nelson, P., Patil, C., Copp\&amp;\#233;, J.-P., Rodier, F., Sun, Y., Goldstein, J., Munoz, D., Desprez, P.-Y., 2008. Senescence-Associated Secretory Phenotypes Reveal Cell-Nonautonomous Functions of Oncogenic RAS and the p53 Tumor Suppressor. Public Libr. Sci.

Cawthon, R.M., 2009. Telomere length measurement by a novel monochrome multiplex quantitative PCR method. Nucleic Acids Res. 37, e21. doi:10.1093/nar/gkn1027

Cawthon, R.M., 2002. Telomere measurement by quantitative PCR. Nucleic Acids Res. 30, e47.

Chang, J., Wang, Y., Shao, L., Laberge, R.-M., Demaria, M., Campisi, J., Janakiraman, K., 
Sharpless, N.E., Ding, S., Feng, W., Luo, Y., Wang, X., Aykin-Burns, N., Krager, K., Ponnappan, U., Hauer-Jensen, M., Meng, A., Zhou, D., 2016. Clearance of senescent cells by ABT263 rejuvenates aged hematopoietic stem cells in mice. Nat. Med. 22, 7883. doi:10.1038/nm.4010

Chapman, J.R., Taylor, M.R.G., Boulton, S.J., 2012. Playing the end game: DNA doublestrand break repair pathway choice. Mol. Cell 47, 497-510. doi:10.1016/j.molcel.2012.07.029

Chen, J.-H., Hales, C.N., Ozanne, S.E., 2007. DNA damage, cellular senescence and organismal ageing: causal or correlative? Nucleic Acids Res. 35, 7417-28. doi:10.1093/nar/gkm681

Chondrogianni, N., Gonos, E.S., 2004. Proteasome inhibition induces a senescence-like phenotype in primary human fibroblasts cultures. Biogerontology 5, 55-61.

Chondrogianni, N., Stratford, F.L.L., Trougakos, I.P., Friguet, B., Rivett, A.J., Gonos, E.S., 2003. Central role of the proteasome in senescence and survival of human fibroblasts: induction of a senescence-like phenotype upon its inhibition and resistance to stress upon its activation. J. Biol. Chem. 278, 28026-37. doi:10.1074/jbc.M301048200

Christensen, K., Doblhammer, G., Rau, R., Vaupel, J.W., 2009. Ageing populations: the challenges ahead. Lancet 374, 1196-208. doi:10.1016/S0140-6736(09)61460-4

Coppé, J.-P., Desprez, P.-Y., Krtolica, A., Campisi, J., 2010. The senescence-associated secretory phenotype: the dark side of tumor suppression. Annu. Rev. Pathol. 5, 99-118. doi:10.1146/annurev-pathol-121808-102144

Coppé, J.-P., Patil, C.K., Rodier, F., Sun, Y., Muñoz, D.P., Goldstein, J., Nelson, P.S., Desprez, P.-Y., Campisi, J., 2008. Senescence-associated secretory phenotypes reveal cell-nonautonomous functions of oncogenic RAS and the p53 tumor suppressor. PLoS Biol. 6, 2853-68. doi:10.1371/journal.pbio.0060301

Cosgrove, B.D., Gilbert, P.M., Porpiglia, E., Mourkioti, F., Lee, S.P., Corbel, S.Y., Llewellyn, M.E., Delp, S.L., Blau, H.M., 2014. Rejuvenation of the muscle stem cell population restores strength to injured aged muscles. Nat. Med. 20, 255-264. doi:10.1038/nm.3464 
Darling, E.M., Topel, M., Zauscher, S., Vail, T.P., Guilak, F., 2008. Viscoelastic properties of human mesenchymally-derived stem cells and primary osteoblasts, chondrocytes, and adipocytes. J. Biomech. 41, 454-64. doi:10.1016/j.jbiomech.2007.06.019

De Cecco, M., Jeyapalan, J., Zhao, X., Tamamori-Adachi, M., Sedivy, J.M., 2011. Nuclear protein accumulation in cellular senescence and organismal aging revealed with a novel single-cell resolution fluorescence microscopy assay. Aging (Albany. NY). 3, 955-67.

Debacq-Chainiaux, F., Erusalimsky, J.D., Campisi, J., Toussaint, O., 2009. Protocols to detect senescence-associated beta-galactosidase (SA-betagal) activity, a biomarker of senescent cells in culture and in vivo. Nat. Protoc. 4, 1798-806. doi:10.1038/nprot.2009.191

Demaria, M., Ohtani, N., Youssef, S.A., Rodier, F., Toussaint, W., Mitchell, J.R., Laberge, R.-M., Vijg, J., Van Steeg, H., Dollé, M.E.T., Hoeijmakers, J.H.J., de Bruin, A., Hara, E., Campisi, J., 2014. An essential role for senescent cells in optimal wound healing through secretion of PDGF-AA. Dev. Cell 31, 722-33. doi:10.1016/j.devcel.2014.11.012

Dierick, J.-F., Eliaers, F., Remacle, J., Raes, M., Fey, S.J., Larsen, P.M., Toussaint, O., 2002. Stress-induced premature senescence and replicative senescence are different phenotypes, proteomic evidence. Biochem. Pharmacol. 64, 1011-7.

Dimri, G.P., Lee, X., Basile, G., Acosta, M., Scott, G., Roskelley, C., Medrano, E.E., Linskens, M., Rubelj, I., Pereira-Smith, O., 1995. A biomarker that identifies senescent human cells in culture and in aging skin in vivo. Proc. Natl. Acad. Sci. U. S. A. 92, 9363-7.

Dumitrescu, R.G., 2012. Epigenetic markers of early tumor development. Methods Mol. Biol. 863, 3-14. doi:10.1007/978-1-61779-612-8_1

Elsedawy, N.B., Russell, S.J., 2013. Oncolytic vaccines. Expert Rev. Vaccines 12, 1155-72. doi:10.1586/14760584.2013.836912

Erusalimsky, J.D., Kurz, D.J., 2005. Cellular senescence in vivo: its relevance in ageing and cardiovascular disease. Exp. Gerontol. 40, 634-42. doi:10.1016/j.exger.2005.04.010

Ervasti, J.M., 2000. Structure and Function of the Dystrophin-Glycoprotein Complex. 
Espinoza, S.E., Guo, H., Fedarko, N., DeZern, A., Fried, L.P., Xue, Q.-L., Leng, S., Beamer, B., Walston, J.D., 2008. Glutathione peroxidase enzyme activity in aging. J. Gerontol. A. Biol. Sci. Med. Sci. 63, 505-9.

Everts, M., Curiel, D.T., 2004. Transductional targeting of adenoviral cancer gene therapy. Curr. Gene Ther. 4, 337-46.

Falandry, C., Gilson, E., Rudolph, K.L., 2013. Are aging biomarkers clinically relevant in oncogeriatrics? Crit. Rev. Oncol. Hematol. 85, 257-65. doi:10.1016/j.critrevonc.2012.08.004

Fan, L.M., Li, J.-M.,. Evaluation of methods of detecting cell reactive oxygen species production for drug screening and cell cycle studies. J. Pharmacol. Toxicol. Methods 70, 40-7. doi:10.1016/j.vascn.2014.03.173

Ferbeyre, G., de Stanchina, E., Querido, E., Baptiste, N., Prives, C., Lowe, S.W., 2000. PML is induced by oncogenic ras and promotes premature senescence. Genes Dev. 14, 201527.

Fulop, T., Le Page, A., Garneau, H., Azimi, N., Baehl, S., Dupuis, G., Pawelec, G., Larbi, A., 2012a. Aging, immunosenescence and membrane rafts: the lipid connection. Longev. Heal. 1, 6. doi:10.1186/2046-2395-1-6

Fulop, T., Le Page, A., Garneau, H., Azimi, N., Baehl, S., Dupuis, G., Pawelec, G., Larbi, A., 2012b. Aging, immunosenescence and membrane rafts: the lipid connection. Longev. Heal. 1, 6. doi:10.1186/2046-2395-1-6

Fumagalli, M., Rossiello, F., Clerici, M., Barozzi, S., Cittaro, D., Kaplunov, J.M., Bucci, G., Dobreva, M., Matti, V., Beausejour, C.M., Herbig, U., Longhese, M.P., d'Adda di Fagagna, F., 2012. Telomeric DNA damage is irreparable and causes persistent DNAdamage-response activation. Nat. Cell Biol. 14, 355-65. doi:10.1038/ncb2466

Fischer, B.M., Wong, J.K., Degan, S., Kummarapurugu, A.B., Zheng, S., Haridass, P., Voynow, J.A., 2013. Increased expression of senescence markers in cystic fibrosis airways. Am. J. Physiol. Lung Cell. Mol. Physiol. 304, L394-400. doi:10.1152/ajplung.00091.2012

G. J. Aan, H.A.H., 2011. Differential Protein Expression in Senescent Human Skin 
Fibroblasts and Stress Induced Premature Senescence (SIPS) Fibroblasts. Sains Malaysiana 40, 1247 - 1253.

Garber, K., 2006. China approves world's first oncolytic virus therapy for cancer treatment. J. Natl. Cancer Inst. 98, 298-300. doi:10.1093/jnci/djj111

García-Prat, L., Martínez-Vicente, M., Perdiguero, E., Ortet, L., Rodríguez-Ubreva, J., Rebollo, E., Ruiz-Bonilla, V., Gutarra, S., Ballestar, E., Serrano, A.L., Sandri, M., Muñoz-Cánoves, P., 2016. Autophagy maintains stemness by preventing senescence. Nature 529, 37-42. doi:10.1038/nature16187

Georgila, K., Voutetakis, K., Delitsikou, V., Chondrogianni, N., Gonos, E.S., 2014. Optimization of in vitro measurement of proteasome activity in mammalian cells using fluorogenic substrates. Free Radic. Biol. Med. 75 Suppl 1, S31. doi:10.1016/j.freeradbiomed.2014.10.762

Ghosh, A.K., Kanda, T., Steele, R., Ray, R.B., 2008. Knockdown of MBP-1 in human foreskin fibroblasts induces p53-p21 dependent senescence. PLoS One 3, e3384. doi:10.1371/journal.pone.0003384

Golde, T.E., Miller, V.M., 2009. Proteinopathy-induced neuronal senescence: a hypothesis for brain failure in Alzheimer's and other neurodegenerative diseases. Alzheimers. Res. Ther. 1, 5. doi:10.1186/alzrt5

Gratzner, H.G., 1982. Monoclonal antibody to 5-bromo- and 5-iododeoxyuridine: A new reagent for detection of DNA replication. Science 218, 474-5.

Gu, L., Kitamura, M., 2012. Sensitive detection and monitoring of senescence-associated secretory phenotype by SASP-RAP assay. PLoS One 7, e52305. doi:10.1371/journal.pone.0052305

Guo, X., Keyes, W.M., Papazoglu, C., Zuber, J., Li, W., Lowe, S.W., Vogel, H., Mills, A.A., 2009. TAp63 induces senescence and suppresses tumorigenesis in vivo. Nat. Cell Biol. 11, 1451-7. doi:10.1038/ncb1988

Harman, D., 1956. Aging: a theory based on free radical and radiation chemistry. J. Gerontol. $11,298-300$.

Harper, S., 2014. Economic and social implications of aging societies. Science 346, 587-91. 
doi:10.1126/science.1254405

Hayflick, L., 1965. The limited in vitro lifetime of human diploid cell strains. Exp. Cell Res. $37,614-36$.

Henry, N.L., Hayes, D.F., 2012. Cancer biomarkers. Mol. Oncol. 6, 140-6. doi:10.1016/j.molonc.2012.01.010

Herbig, U., Ferreira, M., Condel, L., Carey, D., Sedivy, J.M., 2006. Cellular senescence in aging primates. Science 311, 1257. doi:10.1126/science.1122446

Hildebrand, D.G., Lehle, S., Borst, A., Haferkamp, S., Essmann, F., Schulze-Osthoff, K., 2013. $\alpha$-Fucosidase as a novel convenient biomarker for cellular senescence. Cell Cycle 12, 1922-7. doi:10.4161/cc.24944

Hipkiss, A.R., 2006. Accumulation of altered proteins and ageing: causes and effects. Exp. Gerontol. 41, 464-73. doi:10.1016/j.exger.2006.03.004

Holleran, B.J., 2003. Differential recruitment of alpha2beta1 and alpha4beta1 integrins to lipid rafts in Jurkat $\mathrm{T}$ lymphocytes exposed to collagen type IV and fibronectin. J. Leukoc. Biol. 73, 243-252. doi:10.1189/jlb.0902439

Horvath, S., 2013. DNA methylation age of human tissues and cell types. Genome Biol. 14, R115. doi:10.1186/gb-2013-14-10-r115

Huang, Y., Corbley, M.J., Tang, Z., Yang, L., Peng, Y., Zhang, Z.Y., Tong, T.J., 2004. Down-regulation of p21WAF1 promotes apoptosis in senescent human fibroblasts: involvement of retinoblastoma protein phosphorylation and delay of cellular aging. $\mathrm{J}$. Cell. Physiol. 201, 483-91. doi:10.1002/jcp.20125

Hultdin, M., Gronlund, E., Norrback, K.-F., Eriksson-Lindstrom, E., Roos, G., Just, T., 1998. Telomere analysis by fluorescence in situ hybridization and flow cytometry. Nucleic Acids Res. 26, 3651-3656. doi:10.1093/nar/26.16.3651

Ide, T., Tsuji, Y., Ishibashi, S., Mitsui, Y., 1983. Reinitiation of host DNA synthesis in senescent human diploid cells by infection with Simian virus 40. Exp. Cell Res. 143, 343-9.

Irvine, K.M., Skoien, R., Bokil, N.J., Melino, M., Thomas, G.P., Loo, D., Gabrielli, B., Hill, 
M.M., Sweet, M.J., Clouston, A.D., Powell, E.E., 2014. Senescent human hepatocytes express a unique secretory phenotype and promote macrophage migration. World J. Gastroenterol. 20, 17851-62. doi:10.3748/wjg.v20.i47.17851

Jeyapalan, J.C., Ferreira, M., Sedivy, J.M., Herbig, U., 2007. Accumulation of senescent cells in mitotic tissue of aging primates. Mech. Ageing Dev. 128, 36-44. doi:10.1016/j.mad.2006.11.008

Jiang, H., Schiffer, E., Song, Z., Wang, J., Zürbig, P., Thedieck, K., Moes, S., Bantel, H., Saal, N., Jantos, J., Brecht, M., Jenö, P., Hall, M.N., Hager, K., Manns, M.P., Hecker, H., Ganser, A., Döhner, K., Bartke, A., Meissner, C., Mischak, H., Ju, Z., Rudolph, K.L., 2008. Proteins induced by telomere dysfunction and DNA damage represent biomarkers of human aging and disease. Proc. Natl. Acad. Sci. U. S. A. 105, 11299-304. doi:10.1073/pnas.0801457105

Jones, B., 2012. Epigenetics: detecting the dynamics and memory of heterochromatin. Nat. Rev. Genet. 13, 517. doi:10.1038/nrg3283

Kabouridis, P.S., 2006. Lipid rafts in T cell receptor signalling . Mol. Membr. Biol. 23, 4957. doi:10.1080/09687860500453673

Kankeu, H.T., Saksena, P., Xu, K., Evans, D.B., 2013. The financial burden from noncommunicable diseases in low- and middle-income countries: a literature review. Health Res. Policy Syst. 11, 31. doi:10.1186/1478-4505-11-31

Kennedy, S.R., Loeb, L.A., Herr, A.J., 2012. Somatic mutations in aging, cancer and neurodegeneration. Mech. Ageing Dev. 133, 118-26. doi:10.1016/j.mad.2011.10.009

Kim, M.S., Jo, S., Park, J.T., Shin, H.Y., Kim, S.S., Gurel, O., Park, S.C., 2015. Method to purify and analyze heterogeneous senescent cell populations using a microfluidic filter with uniform fluidic profile. Anal. Chem. 87, 9584-8. doi:10.1021/acs.analchem.5b00445

Kosar, M., Bartkova, J., Hubackova, S., Hodny, Z., Lukas, J., Bartek, J., 2011. Senescenceassociated heterochromatin foci are dispensable for cellular senescence, occur in a cell type- and insult-dependent manner and follow expression of p16(ink4a). Cell Cycle 10, 457-68. 
Krishnamurthy, J., Torrice, C., Ramsey, M.R., Kovalev, G.I., Al-Regaiey, K., Su, L., Sharpless, N.E., 2004. Ink4a/Arf expression is a biomarker of aging. J. Clin. Invest. 114, 1299-307. doi:10.1172/JCI22475

Kuilman, T., Michaloglou, C., Vredeveld, L.C.W., Douma, S., van Doorn, R., Desmet, C.J., Aarden, L.A., Mooi, W.J., Peeper, D.S., 2008. Oncogene-induced senescence relayed by an interleukin-dependent inflammatory network. Cell 133, 1019-31. doi:10.1016/j.cell.2008.03.039

Kurz, D.J., Decary, S., Hong, Y., Erusalimsky, J.D., 2000. Senescence-associated (beta)galactosidase reflects an increase in lysosomal mass during replicative ageing of human endothelial cells. J. Cell Sci. 113 ( Pt 2, 3613-22.

Lagerholm, B.C., Weinreb, G.E., Jacobson, K., Thompson, N.L., 2005. Detecting microdomains in intact cell membranes. Annu. Rev. Phys. Chem. 56, 309-36. doi:10.1146/annurev.physchem.56.092503.141211

Larbi, A., Douziech, N., Dupuis, G., Khalil, A., Pelletier, H., 2004. Age-associated alterations in the recruitment of signal- transduction proteins to lipid rafts in human $\mathrm{T}$ lymphocytes Abstract: Aging is associated with a decline in $\mathrm{T}$ cell activation and proliferation, but the underlying ings suggest that lipid rafts ac. J. Leukoc. Biol. 75, 373-381. doi:10.1189/jlb.0703319.1

Larbi, A., Dupuis, G., Khalil, A., Douziech, N., Fortin, C., Fülöp, T., 2006. Differential role of lipid rafts in the functions of CD4+ and CD8+ human T lymphocytes with aging. Cell. Signal. 18, 1017-30. doi:10.1016/j.cellsig.2005.08.016

Larson, C., Oronsky, B., Scicinski, J., Fanger, G.R., Stirn, M., Oronsky, A., Reid, T.R., 2015. Going viral: a review of replication-selective oncolytic adenoviruses. Oncotarget 6, 19976-89.

Lawless, C., Wang, C., Jurk, D., Merz, A., Zglinicki, T. von, Passos, J.F., 2010. Quantitative assessment of markers for cell senescence. Exp. Gerontol. 45, 772-8. doi:10.1016/j.exger.2010.01.018

Lee, B.Y., Han, J.A., Im, J.S., Morrone, A., Johung, K., Goodwin, E.C., Kleijer, W.J., DiMaio, D., Hwang, E.S., 2006. Senescence-associated beta-galactosidase is lysosomal beta-galactosidase. Aging Cell 5, 187-95. doi:10.1111/j.1474-9726.2006.00199.x 
Lee, C.Y.F., Bu, L.X.X., DeBenedetti, A., Williams, B.J., Rennie, P.S., Jia, W.W.G., 2010. Transcriptional and translational dual-regulated oncolytic herpes simplex virus type 1 for targeting prostate tumors. Mol. Ther. 18, 929-35. doi:10.1038/mt.2010.26

Leikam, C., Hufnagel, A.L., Otto, C., Murphy, D.J., Mühling, B., Kneitz, S., Nanda, I., Schmid, M., Wagner, T.U., Haferkamp, S., Bröcker, E.-B., Schartl, M., Meierjohann, S., 2015. In vitro evidence for senescent multinucleated melanocytes as a source for tumorinitiating cells. Cell Death Dis. 6, e1711. doi:10.1038/cddis.2015.71

Li, L., Bhatia, R., 2011. Stem cell quiescence. Clin. Cancer Res. 17, 4936-41. doi:10.1158/1078-0432.CCR-10-1499

Li, Y., Yuan, H., Yang, K., Xu, W., Tang, W., Li, X., 2010. The structure and functions of Pglycoprotein. Curr. Med. Chem. 17, 786-800.

Liang, M., 2012. Clinical development of oncolytic viruses in China. Curr. Pharm. Biotechnol. 13, 1852-7.

Liggett, S.B., Tepe, N.M., Lorenz, J.N., Canning, A.M., Jantz, T.D., Mitarai, S., Yatani, A., Dorn, G.W., 2000. Early and delayed consequences of beta(2)-adrenergic receptor overexpression in mouse hearts: critical role for expression level. Circulation 101, 170714.

Liochev, S.I., 2013. Reactive oxygen species and the free radical theory of aging. Free Radic. Biol. Med. 60, 1-4. doi:10.1016/j.freeradbiomed.2013.02.011

Liu, H., Ding, Y., Voskuhl, R.R., 2005. Method to detect functional estrogen receptor expression using estrogen receptor probing compound. J. Immunoassay Immunochem. 26, 295-301. doi:10.1080/15321810500220894

Lu, Y.-Y., Yang, X., Chen, W.-Q., Ju, Z.-Y., Shou, Z.-F., Jin, J., Zhang, X.-H., Chen, J.-H., Jiang, H., 2014. Proteins induced by telomere dysfunction are associated with human IgA nephropathy. J. Zhejiang Univ. Sci. B 15, 566-74. doi:10.1631/jzus.B1300115

Lynch, M.D., 2004. The role of cellular senescence may be to prevent proliferation of neighboring cells within stem cell niches. Ann. N. Y. Acad. Sci. 1019, 191-4. doi:10.1196/annals. 1297.030

Mäbert, K., Cojoc, M., Peitzsch, C., Kurth, I., Souchelnytskyi, S., Dubrovska, A., 2014. 
Cancer biomarker discovery: Current status and future perspectives. Int. J. Radiat. Biol. 90, 659-77. doi:10.3109/09553002.2014.892229

Maciel-Barón, L.A., Morales-Rosales, S.L., Aquino-Cruz, A.A., Triana-Martínez, F., GalvánArzate, S., Luna-López, A., González-Puertos, V.Y., López-Díazguerrero, N.E., Torres, C., Königsberg, M., 2016. Senescence associated secretory phenotype profile from primary lung mice fibroblasts depends on the senescence induction stimuli. Age (Dordr). 38, 26. doi:10.1007/s11357-016-9886-1

Madamanchi, A., 2007. Beta-adrenergic receptor signaling in cardiac function and heart failure. Mcgill J. Med. 10, 99-104.

Mather, K.A., Jorm, A.F., Parslow, R.A., Christensen, H., 2011. Is telomere length a biomarker of aging? A review. J. Gerontol. A. Biol. Sci. Med. Sci. 66, 202-13. doi:10.1093/gerona/glq180

Baker, D.J., Childs, B.G., Durik, M., Wijers, M.E., Sieben, C.J., Zhong, J., Saltness, R.A., Jeganathan, K.B., Casaclang Verzosa, G., Pezeshki, A., Khazaie, K., Miller, J.D., Van Deursen, J.M., 2016. Naturally occurring p16 Ink4a -positive cells shorten healthy lifespan. Nature 530, 184-189. doi:10.1038/nature16932

Baker, D.J., Wijshake, T., Tchkonia, T., LeBrasseur, N.K., Childs, B.G., van de Sluis, B., Kirkland, J.L., van Deursen, J.M., 2011. Clearance of p16Ink4a-positive senescent cells delays ageing-associated disorders. Nature 479, 232-6. doi:10.1038/nature10600

Bassaneze, V., Miyakawa, A.A., Krieger, J.E., 2008. A quantitative chemiluminescent method for studying replicative and stress-induced premature senescence in cell cultures. Anal. Biochem. 372, 198-203. doi:10.1016/j.ab.2007.08.016

Beauséjour, C.M., Krtolica, A., Galimi, F., Narita, M., Lowe, S.W., Yaswen, P., Campisi, J., 2003. Reversal of human cellular senescence: Roles of the p53 and p16 pathways. EMBO J. 22, 4212-4222. doi:10.1093/emboj/cdg417

Chang, J., Wang, Y., Shao, L., Laberge, R.-M., Demaria, M., Campisi, J., Janakiraman, K., Sharpless, N.E., Ding, S., Feng, W., Luo, Y., Wang, X., Aykin-Burns, N., Krager, K., Ponnappan, U., Hauer-Jensen, M., Meng, A., Zhou, D., 2016. Clearance of senescent cells by ABT263 rejuvenates aged hematopoietic stem cells in mice. Nat. Med. 22, 7883. doi:10.1038/nm.4010 
Christensen, K., Doblhammer, G., Rau, R., Vaupel, J.W., 2009. Ageing populations: the challenges ahead. Lancet 374, 1196-208. doi:10.1016/S0140-6736(09)61460-4

Coppé, J.-P., Desprez, P.-Y., Krtolica, A., Campisi, J., 2010. The senescence-associated secretory phenotype: the dark side of tumor suppression. Annu. Rev. Pathol. 5, 99-118. doi:10.1146/annurev-pathol-121808-102144

De Cecco, M., Jeyapalan, J., Zhao, X., Tamamori-Adachi, M., Sedivy, J.M., 2011. Nuclear protein accumulation in cellular senescence and organismal aging revealed with a novel single-cell resolution fluorescence microscopy assay. Aging (Albany. NY). 3, 955-67.

Dimri, G.P., Lee, X., Basile, G., Acosta, M., Scott, G., Roskelley, C., Medrano, E.E., Linskens, M., Rubelj, I., Pereira-Smith, O., 1995. A biomarker that identifies senescent human cells in culture and in aging skin in vivo. Proc. Natl. Acad. Sci. U. S. A. 92, 9363-7.

Fan, L.M., Li, J.-M., 2014. Evaluation of methods of detecting cell reactive oxygen species production for drug screening and cell cycle studies. J. Pharmacol. Toxicol. Methods 70, 40-7. doi:10.1016/j.vascn.2014.03.173

Ferbeyre, G., de Stanchina, E., Querido, E., Baptiste, N., Prives, C., Lowe, S.W., 2000. PML is induced by oncogenic ras and promotes premature senescence. Genes Dev. 14, 201527.

Garber, K., 2006. China approves world's first oncolytic virus therapy for cancer treatment. J. Natl. Cancer Inst. 98, 298-300. doi:10.1093/jnci/djj111

Ghosh, A.K., Kanda, T., Steele, R., Ray, R.B., 2008. Knockdown of MBP-1 in human foreskin fibroblasts induces p53-p21 dependent senescence. PLoS One 3, e3384. doi:10.1371/journal.pone.0003384

Harman, D., 1956. Aging: a theory based on free radical and radiation chemistry. J. Gerontol. $11,298-300$.

Harper, S., 2014. Economic and social implications of aging societies. Science 346, 587-91. doi:10.1126/science.1254405

Hayflick, L., 1965. The limited in vitro lifetime of human diploid cell strains. Exp. Cell Res. 37, 614-36. 
Hildebrand, D.G., Lehle, S., Borst, A., Haferkamp, S., Essmann, F., Schulze-Osthoff, K., 2013. $\alpha$-Fucosidase as a novel convenient biomarker for cellular senescence. Cell Cycle 12, 1922-7. doi:10.4161/cc.24944

Ide, T., Tsuji, Y., Ishibashi, S., Mitsui, Y., 1983. Reinitiation of host DNA synthesis in senescent human diploid cells by infection with Simian virus 40. Exp. Cell Res. 143, 343-9.

Kankeu, H.T., Saksena, P., Xu, K., Evans, D.B., 2013. The financial burden from noncommunicable diseases in low- and middle-income countries: a literature review. Health Res. Policy Syst. 11, 31. doi:10.1186/1478-4505-11-31

Kurz, D.J., Decary, S., Hong, Y., Erusalimsky, J.D., 2000. Senescence-associated (beta)galactosidase reflects an increase in lysosomal mass during replicative ageing of human endothelial cells. J. Cell Sci. 113 ( Pt 2, 3613-22.

Lynch, M.D., 2004. The role of cellular senescence may be to prevent proliferation of neighboring cells within stem cell niches. Ann. N. Y. Acad. Sci. 1019, 191-4. doi:10.1196/annals.1297.030

Maciel-Barón, L.A., Morales-Rosales, S.L., Aquino-Cruz, A.A., Triana-Martínez, F., GalvánArzate, S., Luna-López, A., González-Puertos, V.Y., López-Díazguerrero, N.E., Torres, C., Königsberg, M., 2016. Senescence associated secretory phenotype profile from primary lung mice fibroblasts depends on the senescence induction stimuli. Age (Dordr). 38, 26. doi:10.1007/s11357-016-9886-1

Melk, A., Schmidt, B.M.W., Braun, H., Vongwiwatana, A., Urmson, J., Zhu, L.-F., Rayner, D., Halloran, P.F., 2009. Effects of donor age and cell senescence on kidney allograft survival. Am. J. Transplant 9, 114-23. doi:10.1111/j.1600-6143.2008.02500.x

Narita, M., 2007. Cellular senescence and chromatin organisation. Br. J. Cancer 96, 686-91. doi:10.1038/sj.bjc.6603636

Park, D.C., Yeo, S.G., 2013. Aging. Korean J. Audiol. 17, 39-44. doi:10.7874/kja.2013.17.2.39

Pol, J., Kroemer, G., Galluzzi, L., 2015. First oncolytic virus approved for melanoma immunotherapy. Oncoimmunology 5, e1115641. doi:10.1080/2162402X.2015.1115641 
Rodier, F., Coppé, J.-P., Patil, C.K., Hoeijmakers, W.A.M., Muñoz, D.P., Raza, S.R., Freund, A., Campeau, E., Davalos, A.R., Campisi, J., 2009. Persistent DNA damage signalling triggers senescence-associated inflammatory cytokine secretion. Nat. Cell Biol. 11, 9739. doi:10.1038/ncb1909

Sinclair, D.A., Oberdoerffer, P., 2009. The ageing epigenome: damaged beyond repair? Ageing Res. Rev. 8, 189-98. doi:10.1016/j.arr.2009.04.004

Wei, Y.H., Ma, Y.S., Lee, H.C., Lee, C.F., Lu, C.Y., 2001. Mitochondrial theory of aging matures--roles of mtDNA mutation and oxidative stress in human aging. Zhonghua Yi Xue Za Zhi (Taipei). 64, 259-70.

Willoughby, N.A., Bock, H., Hoeve, M.A., Pells, S., Williams, C., McPhee, G., Freile, P., Choudhury, D., De Sousa, P.A., 2016. A scalable label-free approach to separate human pluripotent cells from differentiated derivatives. Biomicrofluidics 10, 014107. doi:10.1063/1.4939946

Wimo, A., Jönsson, L., Bond, J., Prince, M., Winblad, B., 2013. The worldwide economic impact of dementia 2010. Alzheimers. Dement. 9, 1-11.e3. doi:10.1016/j.jalz.2012.11.006

Yang, N.-C., Hu, M.-L., 2005. The limitations and validities of senescence associated-betagalactosidase activity as an aging marker for human foreskin fibroblast Hs68 cells. Exp. Gerontol. 40, 813-9. doi:10.1016/j.exger.2005.07.011

Zhu, Y., Tchkonia, T., Fuhrmann-Stroissnigg, H., Dai, H.M., Ling, Y.Y., Stout, M.B., Pirtskhalava, T., Giorgadze, N., Johnson, K.O., Giles, C.B., Wren, J.D., Niedernhofer, L.J., Robbins, P.D., Kirkland, J.L., 2015. Identification of a Novel Senolytic Agent, Navitoclax, Targeting the Bcl-2 Family of Anti-Apoptotic Factors. Aging Cell. doi:10.1111/acel.12445

Mikhalyov, I., Samsonov, A., 2011. Lipid raft detecting in membranes of live erythrocytes. Biochim. Biophys. Acta 1808, 1930-9. doi:10.1016/j.bbamem.2011.04.002

Momchilova, A., Petkova, D., Staneva, G., Markovska, T., Pankov, R., Skrobanska, R., Nikolova-Karakashian, M., Koumanov, K., 2014. Resveratrol alters the lipid composition, metabolism and peroxide level in senescent rat hepatocytes. Chem. Biol. Interact. 207, 74-80. doi:10.1016/j.cbi.2013.10.016 
Muller, P.A.J., Vousden, K.H., 2013. p53 mutations in cancer. Nat. Cell Biol. 15, 2-8. doi: $10.1038 / \mathrm{ncb} 2641$

Muñoz-Espín, D., Cañamero, M., Maraver, A., Gómez-López, G., Contreras, J., MurilloCuesta, S., Rodríguez-Baeza, A., Varela-Nieto, I., Ruberte, J., Collado, M., Serrano, M., 2013. Programmed cell senescence during mammalian embryonic development. Cell 155, 1104-18. doi:10.1016/j.cell.2013.10.019

Narita, M., Nũnez, S., Heard, E., Narita, M., Lin, A.W., Hearn, S.A., Spector, D.L., Hannon, G.J., Lowe, S.W., 2003. Rb-mediated heterochromatin formation and silencing of E2F target genes during cellular senescence. Cell 113, 703-16.

Narita, M., 2007. Cellular senescence and chromatin organisation. Br. J. Cancer 96, 686-91. doi:10.1038/sj.bjc.6603636

Nishimatsu, H., Suzuki, E., Saito, Y., Niimi, A., Nomiya, A., Fukuhara, H., Kume, H., Homma, Y., 2015. Senescent Cells Impair Erectile Function through Induction of Endothelial Dysfunction and Nerve Injury in Mice. PLoS One 10, e0124129. doi:10.1371/journal.pone.0124129

O’Callaghan, N.J., Fenech, M., 2011. A quantitative PCR method for measuring absolute telomere length. Biol. Proced. Online 13, 3. doi:10.1186/1480-9222-13-3

O’Sullivan, J.N., Finley, J.C., Risques, R.-A., Shen, W.-T., Gollahon, K.A., Rabinovitch, P.S., 2005. Quantitative fluorescence in situ hybridization (QFISH) of telomere lengths in tissue and cells. Curr. Protoc. Cytom. Chapter 12, Unit 12.6. doi:10.1002/0471142956.cy1206s33

Obradovic, J., Jurisic, V., 2012. Evaluation of current methods to detect the mutations of epidermal growth factor receptor in non-small cell lung cancer patients. Multidiscip. Respir. Med. 7, 52. doi:10.1186/2049-6958-7-52

Ourliac-Garnier, I., Londoño-Vallejo, A., 2011. Telomere length analysis by quantitative fluorescent in situ hybridization (Q-FISH). Methods Mol. Biol. 735, 21-31. doi:10.1007/978-1-61779-092-8_3

Oishi, T., Imai, H., Go, Y., Imamura, M., Hirai, H., Takada, M., 2014. Sporadic premature aging in a Japanese monkey: a primate model for progeria. PLoS One 9, e111867. 
doi:10.1371/journal.pone.0111867

Pallis, A.G., Hatse, S., Brouwers, B., Pawelec, G., Falandry, C., Wedding, U., Lago, L.D., Repetto, L., Ring, A., Wildiers, H., 2014. Evaluating the physiological reserves of older patients with cancer: the value of potential biomarkers of aging? J. Geriatr. Oncol. 5, 204-18. doi:10.1016/j.jgo.2013.09.001

Paradis, V., Youssef, N., Dargère, D., Bâ, N., Bonvoust, F., Deschatrette, J., Bedossa, P., 2001. Replicative senescence in normal liver, chronic hepatitis C, and hepatocellular carcinomas. Hum. Pathol. 32, 327-32. doi:10.1053/hupa.2001.22747

Park, D.C., Yeo, S.G., 2013. Aging. Korean J. Audiol. 17, 39-44. doi:10.7874/kja.2013.17.2.39

Parrinello, S., Coppe, J.-P., Krtolica, A., Campisi, J., 2005. Stromal-epithelial interactions in aging and cancer: senescent fibroblasts alter epithelial cell differentiation. J. Cell Sci. 118, 485-96. doi:10.1242/jcs.01635

Paul, A., Belton, A., Nag, S., Martin, I., Grotewiel, M.S., Duttaroy, A., 2007. Reduced mitochondrial SOD displays mortality characteristics reminiscent of natural aging. Mech. Ageing Dev. 128, 706-16. doi:10.1016/j.mad.2007.10.013

Paul, M.K., Bisht, B., Darmawan, D.O., Chiou, R., Ha, V.L., Wallace, W.D., Chon, A.T., Hegab, A.E., Grogan, T., Elashoff, D.A., Alva-Ornelas, J.A., Gomperts, B.N., 2014. Dynamic changes in intracellular ROS levels regulate airway basal stem cell homeostasis through Nrf2-dependent Notch signaling. Cell Stem Cell 15, 199-214. doi:10.1016/j.stem.2014.05.009

Perez, J.T., García-Sastre, A., Manicassamy, B., 2013. Insertion of a GFP reporter gene in influenza virus. Curr. Protoc. Microbiol. Chapter 15, Unit 15G.4. doi:10.1002/9780471729259.mc15g04s29

Pol, J., Kroemer, G., Galluzzi, L., 2015. First oncolytic virus approved for melanoma immunotherapy. Oncoimmunology 5, e1115641. doi:10.1080/2162402X.2015.1115641

Pontes, B., Ayala, Y., Fonseca, A.C.C., Romão, L.F., Amaral, R.F., Salgado, L.T., Lima, F.R., Farina, M., Viana, N.B., Moura-Neto, V., Nussenzveig, H.M., 2013. Membrane elastic properties and cell function. PLoS One 8, e67708. 
doi:10.1371/journal.pone.0067708

Poot, M., Verkerk, A., Jongkind, J.F., 1986. Accumulation of a high molecular weight glycoprotein during in vitro ageing and contact inhibition of growth. Mech. Ageing Dev. 34, 219-32.

Reinheckel, T., Sitte, N., Ullrich, O., Kuckelkorn, U., Davies, K.J., Grune, T., 1998. Comparative resistance of the $20 \mathrm{~S}$ and $26 \mathrm{~S}$ proteasome to oxidative stress. Biochem. J. 335 ( Pt 3, 637-42.

Riess, O., Krüger, R., 1999. Parkinson's disease--a multifactorial neurodegenerative disorder. J. Neural Transm. Suppl. 56, 113-25.

Rodier, F., 2013. Detection of the senescence-associated secretory phenotype (SASP). Methods Mol. Biol. 965, 165-73. doi:10.1007/978-1-62703-239-1_10

Rodier, F., Campisi, J., 2011. Four faces of cellular senescence. J. Cell Biol. 192, 547-56. doi:10.1083/jcb.201009094

Rodier, F., Coppé, J.-P., Patil, C.K., Hoeijmakers, W.A.M., Muñoz, D.P., Raza, S.R., Freund, A., Campeau, E., Davalos, A.R., Campisi, J., 2009. Persistent DNA damage signalling triggers senescence-associated inflammatory cytokine secretion. Nat. Cell Biol. 11, 9739. doi:10.1038/ncb1909

Rossi, M.L., Ghosh, A.K., Bohr, V.A., 2010. Roles of Werner syndrome protein in protection of genome integrity. DNA Repair (Amst). 9, 331-44. doi:10.1016/j.dnarep.2009.12.011

Sahin, E., Colla, S., Liesa, M., Moslehi, J., Müller, F.L., Guo, M., Cooper, M., Kotton, D., Fabian, A.J., Walkey, C., Maser, R.S., Tonon, G., Foerster, F., Xiong, R., Wang, Y.A., Shukla, S.A., Jaskelioff, M., Martin, E.S., Heffernan, T.P., Protopopov, A., Ivanova, E., Mahoney, J.E., Kost-Alimova, M., Perry, S.R., Bronson, R., Liao, R., Mulligan, R., Shirihai, O.S., Chin, L., DePinho, R.A., 2011. Telomere dysfunction induces metabolic and mitochondrial compromise. Nature 470, 359-65. doi:10.1038/nature09787

Salama, R., Sadaie, M., Hoare, M., Narita, M., 2014. Cellular senescence and its effector programs. Genes Dev. 28, 99-114. doi:10.1101/gad.235184.113

Salic, A., Mitchison, T.J., 2008. A chemical method for fast and sensitive detection of DNA synthesis in vivo. Proc. Natl. Acad. Sci. U. S. A. 105, 2415-20. 
doi:10.1073/pnas.0712168105

Sandeman, S.R., Faragher, R.G., Allen, M.C., Liu, C., Lloyd, A.W., 2001. Does MMP-2 expression and secretion change with increasing serial passage of keratocytes in culture? Mech. Ageing Dev. 122, 157-67.

Schnabl, B., Purbeck, C.A., Choi, Y.H., Hagedorn, C.H., Brenner, D., 2003. Replicative senescence of activated human hepatic stellate cells is accompanied by a pronounced inflammatory but less fibrogenic phenotype. Hepatology 37, 653-64. doi:10.1053/jhep.2003.50097

Sedelnikova, O.A., Horikawa, I., Zimonjic, D.B., Popescu, N.C., Bonner, W.M., Barrett, J.C., 2004. Senescing human cells and ageing mice accumulate DNA lesions with unrepairable double-strand breaks. Nat. Cell Biol. 6, 168-70. doi:10.1038/ncb1095

Sharma, A., Singh, K., Almasan, A., 2012. Histone H2AX phosphorylation: a marker for DNA damage. Methods Mol. Biol. 920, 613-26. doi:10.1007/978-1-61779-998-3_40

Sharpless, N.E., Sherr, C.J., 2015. Forging a signature of in vivo senescence. Nat. Rev. Cancer 15, 397-408. doi:10.1038/nrc3960

Shay, J.W., Pereira-Smith, O.M., Wright, W.E., 1991. A role for both RB and p53 in the regulation of human cellular senescence. Exp. Cell Res. 196, 33-9.

Sheikh, S., Haque, E., Mir, S.S., 2013. Neurodegenerative Diseases: Multifactorial Conformational Diseases and Their Therapeutic Interventions. J. Neurodegener. Dis. 2013, 1-8. doi:10.1155/2013/563481

Sinclair, D.A., Oberdoerffer, P., 2009. The ageing epigenome: damaged beyond repair? Ageing Res. Rev. 8, 189-98. doi:10.1016/j.arr.2009.04.004

Singh, P.K., Doley, J., Kumar, G.R., Sahoo, A.P., Tiwari, A.K., 2012. Oncolytic viruses \& their specific targeting to tumour cells. Indian J. Med. Res. 136, 571-84.

Starkov, A.A., 2010. Measurement of mitochondrial ROS production. Methods Mol. Biol. 648, 245-55. doi:10.1007/978-1-60761-756-3_16

Sud, M., Fahy, E., Cotter, D., Brown, A., Dennis, E.A., Glass, C.K., Merrill, A.H., Murphy, R.C., Raetz, C.R.H., Russell, D.W., Subramaniam, S., 2007. LMSD: LIPID MAPS 
structure database. Nucleic Acids Res. 35, D527-32. doi:10.1093/nar/gk1838

Suresh, S., 2007. Biomechanics and biophysics of cancer cells. Acta Biomater. 3, 413-38. doi:10.1016/j.actbio.2007.04.002

Suresh, S., Spatz, J., Mills, J.P., Micoulet, A., Dao, M., Lim, C.T., Beil, M., Seufferlein, T., 2005. Connections between single-cell biomechanics and human disease states: gastrointestinal cancer and malaria. Acta Biomater. 1, 15-30. doi:10.1016/j.actbio.2004.09.001

Takai, H., Smogorzewska, A., de Lange, T., 2003. DNA Damage Foci at Dysfunctional Telomeres. Curr. Biol. 13, 1549-1556. doi:10.1016/S0960-9822(03)00542-6

Tominaga, K., 2015. The emerging role of senescent cells in tissue homeostasis and pathophysiology. Pathobiol. Aging Age Relat. Dis. 5, 27743.

Torres, C.A., Perez, V.I., 2008. Proteasome modulates mitochondrial function during cellular senescence. Free Radic. Biol. Med. 44, 403-14. doi:10.1016/j.freeradbiomed.2007.10.002

Toussaint, O., Medrano, E.E., von Zglinicki, T., 2000. Cellular and molecular mechanisms of stress-induced premature senescence (SIPS) of human diploid fibroblasts and melanocytes. Exp. Gerontol. 35, 927-45.

Urruticoechea, A., Smith, I.E., Dowsett, M., 2005. Proliferation marker Ki-67 in early breast cancer. J. Clin. Oncol. 23, 7212-20. doi:10.1200/JCO.2005.07.501

Vacchelli, E., Eggermont, A., Sautès-Fridman, C., Galon, J., Zitvogel, L., Kroemer, G., Galluzzi, L., 2013. Trial watch: Oncolytic viruses for cancer therapy. Oncoimmunology 2, e24612. doi:10.4161/onci.24612

Vandenberk, B., Brouwers, B., Hatse, S., Wildiers, H., 2011. p16INK4a: A central player in cellular senescence and a promising aging biomarker in elderly cancer patients. J. Geriatr. Oncol. 2, 259-269. doi:10.1016/j.jgo.2011.08.004

Verheije, M.H., Rottier, P.J.M., 2012. Retargeting of viruses to generate oncolytic agents. Adv. Virol. 2012, 798526. doi:10.1155/2012/798526

von Zglinicki, T., Saretzki, G., Ladhoff, J., d'Adda di Fagagna, F., Jackson, S.P., 2005. 
Human cell senescence as a DNA damage response. Mech. Ageing Dev. 126, 111-7. doi:10.1016/j.mad.2004.09.034

Voutetakis, K., Chatziioannou, A., Gonos, E.S., Trougakos, I.P., 2015. Comparative MetaAnalysis of Transcriptomics Data during Cellular Senescence and In Vivo Tissue Ageing. Oxid. Med. Cell. Longev. 2015, 1-17. doi:10.1155/2015/732914

Wang, C., Jurk, D., Maddick, M., Nelson, G., Martin-Ruiz, C., von Zglinicki, T., 2009. DNA damage response and cellular senescence in tissues of aging mice. Aging Cell 8, 311-23. doi:10.1111/j.1474-9726.2009.00481.x

Wang, F., Pan, X., Kalmbach, K., Seth-Smith, M.L., Ye, X., Antumes, D.M.F., Yin, Y., Liu, L., Keefe, D.L., Weissman, S.M., 2013. Robust measurement of telomere length in single cells. Proc. Natl. Acad. Sci. U. S. A. 110, E1906-12. doi:10.1073/pnas.1306639110

Wang, J.C., Bennett, M., 2012. Aging and Atherosclerosis: Mechanisms, Functional Consequences, and Potential Therapeutics for Cellular Senescence. Circ. Res. 111, 245259. doi:10.1161/CIRCRESAHA.111.261388

Wang, X., Su, C., Cao, H., Li, K., Chen, J., Jiang, L., Zhang, Q., Wu, X., Jia, X., Liu, Y., Wang, W., Liu, X., Wu, M., Qian, Q., 2008. A novel triple-regulated oncolytic adenovirus carrying p53 gene exerts potent antitumor efficacy on common human solid cancers. Mol. Cancer Ther. 7, 1598-603. doi:10.1158/1535-7163.MCT-07-2429

Webley, K., Bond, J.A., Jones, C.J., Blaydes, J.P., Craig, A., Hupp, T., Wynford-Thomas, D., 2000. Posttranslational modifications of p53 in replicative senescence overlapping but distinct from those induced by DNA damage. Mol. Cell. Biol.

Wei, Y.H., Ma, Y.S., Lee, H.C., Lee, C.F., Lu, C.Y., 2001. Mitochondrial theory of aging matures--roles of mtDNA mutation and oxidative stress in human aging. Zhonghua Yi Xue Za Zhi (Taipei). 64, 259-70.

Willoughby, N.A., Bock, H., Hoeve, M.A., Pells, S., Williams, C., McPhee, G., Freile, P., Choudhury, D., De Sousa, P.A., 2016. A scalable label-free approach to separate human pluripotent cells from differentiated derivatives. Biomicrofluidics 10, 014107. doi:10.1063/1.4939946 
Wimo, A., Jönsson, L., Bond, J., Prince, M., Winblad, B., 2013. The worldwide economic impact of dementia 2010. Alzheimers. Dement. 9, 1-11.e3. doi:10.1016/j.jalz.2012.11.006

Wu, B., Ueno, M., Onodera, M., Kusaka, T., Huang, C., Hosomi, N., Kanenishi, K., Sakamoto, H., 2009. Age-related changes in P-glycoprotein expression in senescenceaccelerated mouse. Curr. Aging Sci. 2, 187-92.

Yang, N.-C., Hu, M.-L., 2005. The limitations and validities of senescence associated-betagalactosidase activity as an aging marker for human foreskin fibroblast Hs68 cells. Exp. Gerontol. 40, 813-9. doi:10.1016/j.exger.2005.07.011

Zacarias-Fluck, M.F., Morancho, B., Vicario, R., Luque Garcia, A., Escorihuela, M., Villanueva, J., Rubio, I.T., Arribas, J., 2015. Effect of cellular senescence on the growth of HER2-positive breast cancers. J. Natl. Cancer Inst. 107, djv020-. doi:10.1093/jnci/djv020

Zietzer, A., Hillmeister, P., 2014. Leucocyte telomere length as marker for cardiovascular ageing. Acta Physiol. (Oxf). 211, 251-6. doi:10.1111/apha.12284

Zhu, Y., Tchkonia, T., Fuhrmann-Stroissnigg, H., Dai, H.M., Ling, Y.Y., Stout, M.B., Pirtskhalava, T., Giorgadze, N., Johnson, K.O., Giles, C.B., Wren, J.D., Niedernhofer, L.J., Robbins, P.D., Kirkland, J.L., 2015. Identification of a Novel Senolytic Agent, Navitoclax, Targeting the Bcl-2 Family of Anti-Apoptotic Factors. Aging Cell. doi:10.1111/acel.12445

Zhu, Y., Tchkonia, T., Pirtskhalava, T., Gower, A.C., Ding, H., Giorgadze, N., Palmer, A.K., Ikeno, Y., Hubbard, G.B., Lenburg, M., O’Hara, S.P., LaRusso, N.F., Miller, J.D., Roos, C.M., Verzosa, G.C., LeBrasseur, N.K., Wren, J.D., Farr, J.N., Khosla, S., Stout, M.B., McGowan, S.J., Fuhrmann-Stroissnigg, H., Gurkar, A.U., Zhao, J., Colangelo, D., Dorronsoro, A., Ling, Y.Y., Barghouthy, A.S., Navarro, D.C., Sano, T., Robbins, P.D., Niedernhofer, L.J., Kirkland, J.L., 2015. The Achilles' heel of senescent cells: from transcriptome to senolytic drugs. Aging Cell 14, 644-58. doi:10.1111/acel.12344 


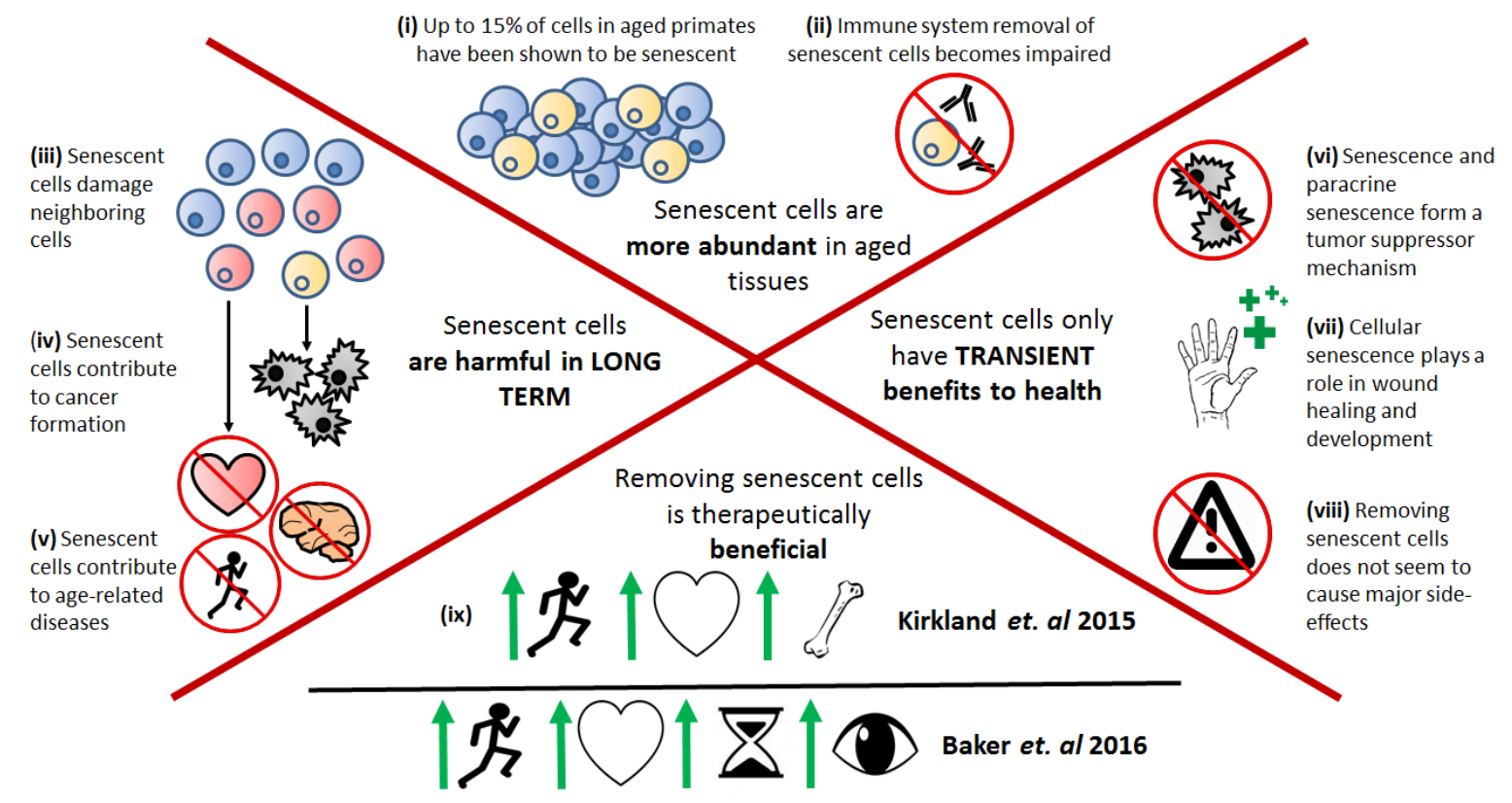

Figure 1| Senescent cell role in health and disease. (i) Senescent cells accumulate in aged primates (Herbig et al., 2006; Oishi et al., 2014), and (ii) their removal might be impaired due to declining efficiency of the immune system. These accumulating senescent cells can (iii) damage surrounding cells (Biran and Krizhanovsky, 2015) and cause (iv) cancer (Leikam et al., 2015) and (v) other agerelated diseases, such as atherosclerosis (Erusalimsky and Kurz, 2005; Fischer et al., 2013; Nishimatsu et al., 2015). Although senescent cells play an important role in (vi) tumor suppression (Tominaga, 2015), (vii) wound healing (Demaria et al., 2014) and development, (viii) periodically removing them does not produce significant side-effects (Baker et al., 2016). Furthermore, (ix) removing senescent cells has been shown to increase health- and life-span in mouse models (Baker et al., 2016, 2011; Chang et al., 2016; Yi Zhu et al., 2015) 


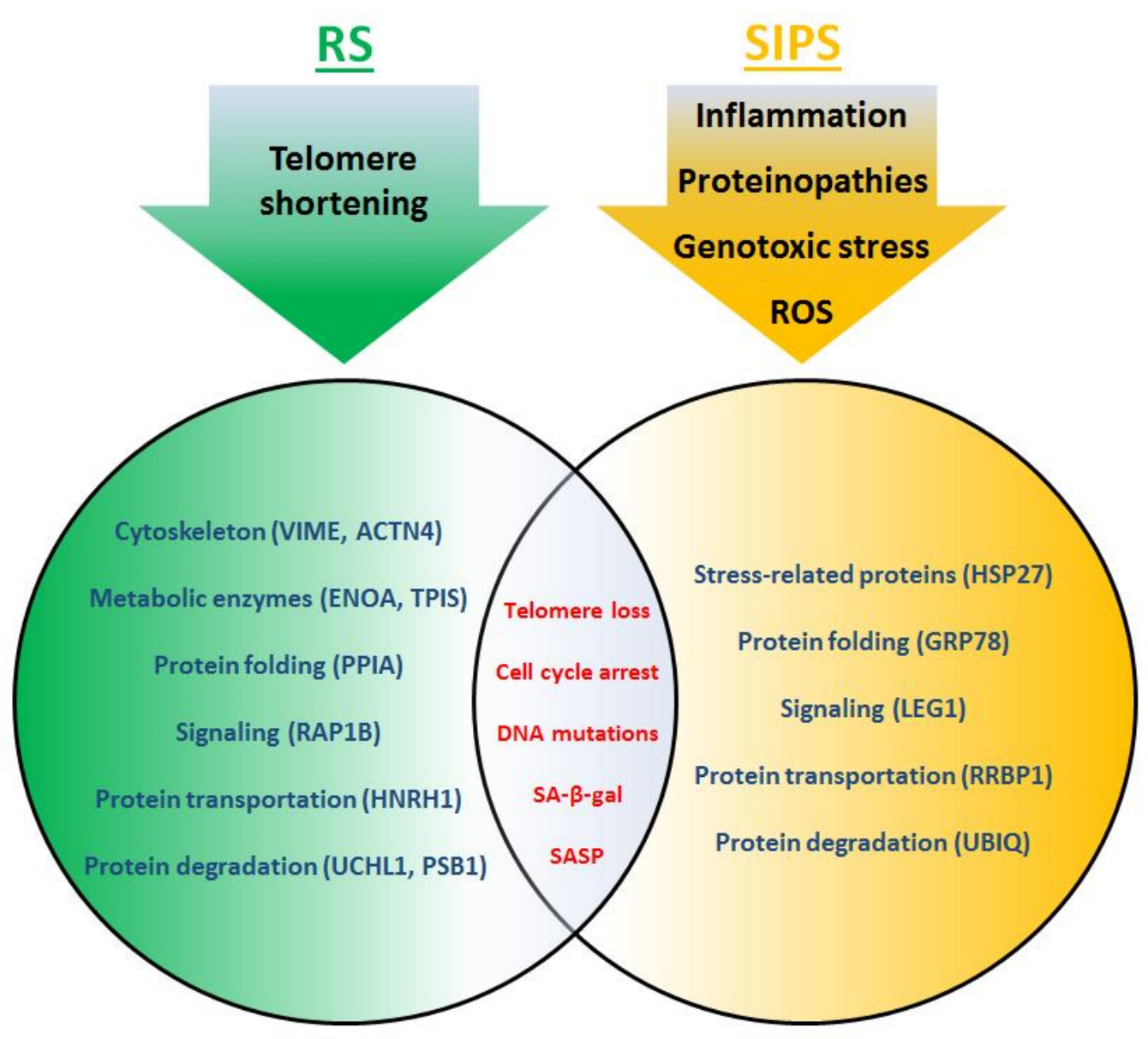

Figure 2| Comparison of replicative senescence (RS) versus stress-induced premature senescence (SIPS). These two different types of senescence have measurably distinct proteomes (text in blue) but share many major senescence phenotypes (text in red). Moreover, it has been shown that different factors are responsible for induction of these phenotypes (Aan et al., 2013; Braig et al., 2014; Chondrogianni and Gonos, 2004; De Cecco et al., 2011; Golde and Miller, 2009). 


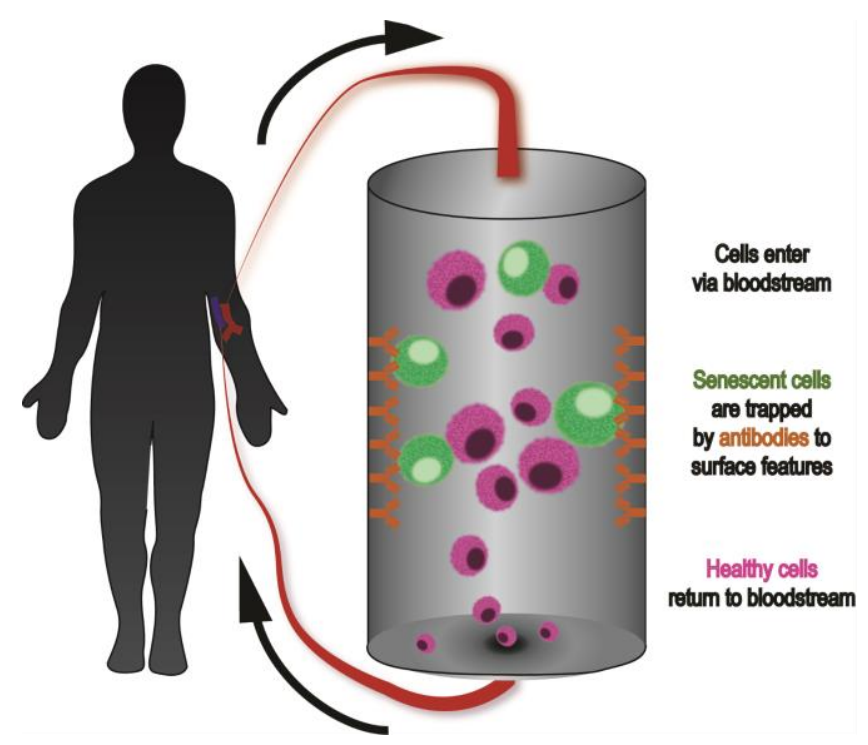

Figure 3| Schematic for the isolation of senescent cells from blood. This schematic demonstrates the principle of isolating senescent cells from the blood using a dialysis approach. This could be applied to humans to clear the blood of senescent cells, which are known to accelerate aging and cancer in neighbouring cells and to interfere with tissue homeostasis.

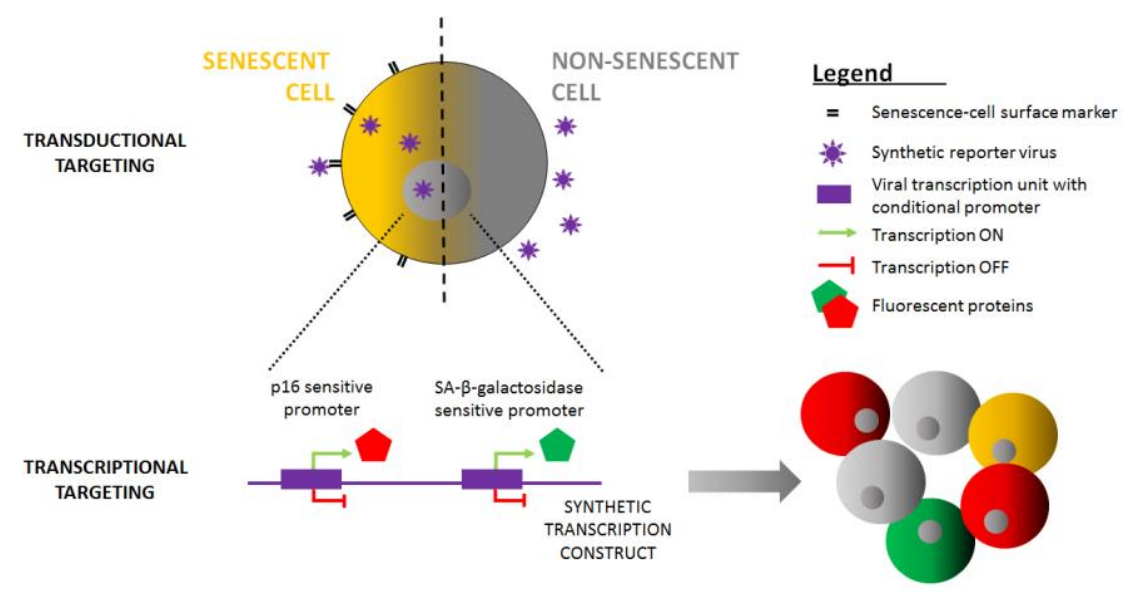

Figure 4| Schematic representation of combinatorial senescent cell targeting with a synthetic reporter virus. This is an example of how a virus could be designed to select senescent cells based on a combination of markers. Viruses can be engineered to enter only cells which have a specific surface marker (transductional targeting). Moreover, simple (as demonstrated in the graph) or more elaborate synthetic genetic circuits could be used to allow reporter expression to occur only in cells possessing multiple markers for senescence, such as an active p16 promoter or an increased SA- $\beta$-galactosidase activity. Replacing fluorescent proteins with suicide genes, which are functional only when expressed together, would allow generation of senescent-cell-specific lytic viruses. Such a senescent cell removal therapy could be used to remove senescent cells in an effort to increase health- and life-span of patients (Baker et al., 2016, 2011; Chang et al., 2016) 
Table 1: Key cellular senescence phenotypic traits and related mechanisms

\begin{tabular}{|c|c|}
\hline Senescent cell phenotypic traits & Reference \\
\hline Permanent cell cycle arrest & Shay et al., 1991 \\
\hline Persistent DNA damage response (DDR) & Fumagalli et al., 2012 \\
\hline $\begin{array}{c}\text { Senescence-associated heterochromatic } \\
\text { foci (SAHFs) and other epigenetic changes }\end{array}$ & Narita et al., 2003 \\
\hline $\begin{array}{r}\text { Senescence associated secretory } \\
\text { phenotype (SASP) }\end{array}$ & García-Prat et al., 2005 2005 \\
\hline $\begin{array}{c}\text { Altered metabolism including increased } \\
\text { lysosomal and proteosomal activity }\end{array}$ & \\
\hline
\end{tabular}


Table 2: A summary of the most practical cellular senescence markers

\begin{tabular}{|c|c|c|}
\hline Marker category & Senescence marker & Detection assays \\
\hline \multirow{4}{*}{$\begin{array}{l}\text { Secretion and } \\
\text { surface }\end{array}$} & SASP and TASP & $\begin{array}{l}\text { SASP-responsive alkaline phosphatase } \\
\text { assay, ELISA, FACS, indirect assays based } \\
\text { on secretions effect to surrounding cells }\end{array}$ \\
\hline & $\begin{array}{c}\text { Plasma membrane-associated } \\
\text { proteins (concanavalin A, fucose, } \\
\text { ICAM-1, DEP1, B2MG, NOTCH3, } \\
\text { DCR2) }\end{array}$ & $\begin{array}{l}\text { Magnetic cell sorting (MACS), } \\
\text { fluorescence-based cell sorting (FACS), } \\
\text { immunocytochemistry }\end{array}$ \\
\hline & $\begin{array}{l}\text { Plasma membrane mechanics } \\
\text { (solidity, cell size) }\end{array}$ & $\begin{array}{c}\text { Electrophysiology techniques, biophysical } \\
\text { techniques (tangential flow filtration) }\end{array}$ \\
\hline & Lipid rafts (LR) & $\begin{array}{l}\text { CTxB fluorescent molecules and other } \\
\text { fluorescent probes }\end{array}$ \\
\hline \multirow{4}{*}{ DNA-associated } & $\begin{array}{l}\text { DNA damage markers ( } \gamma \mathrm{H} 2 \mathrm{AX} \\
\text { 53BPI, Rad17, ATR, ATM, MDC1, TIF) }\end{array}$ & Immunocytochemistry \\
\hline & DNA synthesis & $\begin{array}{l}\text { EdU or BrdU incorporation; Ki-67 } \\
\text { immunocytochemistry }\end{array}$ \\
\hline & Telomere length & Quantitative PCR, FISH \\
\hline & SAHF & CiA, DAPI staining, Immunocytochemistry \\
\hline \multirow{3}{*}{$\begin{array}{l}\text { Damage and } \\
\text { repair } \\
\text { mechanism }\end{array}$} & Proteasome activity & Fluorogenic peptide substrate assay \\
\hline & $\begin{array}{c}\text { Lysosomal activity ( } \beta \text {-Galactosidase, } \\
\alpha \text {-Fucosidase) }\end{array}$ & $\begin{array}{l}\text { Fluorescence, chemiluminescent, } \\
\text { cytochemical methods }\end{array}$ \\
\hline & ROS & $\begin{array}{c}\text { DCFDH-DA } \\
\text { fluorometry, chemiluminescent oxygen } \\
\text { detection reagents, FACS }\end{array}$ \\
\hline \multirow{4}{*}{$\begin{array}{l}\text { Cell-cycle } \\
\text { related }\end{array}$} & p16-pRB axis & \multirow{4}{*}{ Immunocytochemistry, reporter assays } \\
\hline & p53-p21 axis & \\
\hline & DEC1 (BHLHB2) & \\
\hline & PPP1A & \\
\hline
\end{tabular}


Table 3: A list of techniques which could be applied to remove senescent cells

\begin{tabular}{|c|c|c|}
\hline Technique & Advantages & Disadvantages \\
\hline $\begin{array}{l}\text { Blood perfusion } \\
\text { using surface } \\
\text { markers or cell } \\
\text { stiffness }\end{array}$ & $\begin{array}{l}\text { Variations of the technique already } \\
\text { used in clinic }\end{array}$ & $\begin{array}{l}\text { Only able to remove senescent cells } \\
\text { circulating in blood system }\end{array}$ \\
\hline $\begin{array}{l}\text { Magnetic sorting } \\
\text { using } \\
\text { intracellular } \\
\text { marker }\end{array}$ & Established technology exists & $\begin{array}{l}\text { No clinical grade MAC sorter is currently } \\
\text { available }\end{array}$ \\
\hline Lytic virus & $\begin{array}{l}\text { Variations of the technique already } \\
\text { used in clinic }\end{array}$ & Safety concerns of using virotherapy \\
\hline $\begin{array}{l}\text { Stimulating the } \\
\text { immune system }\end{array}$ & Success and promise in oncotherapy & $\begin{array}{c}\text { Lack of robust and unique cell-surface } \\
\text { marker for senescent cells }\end{array}$ \\
\hline $\begin{array}{l}\text { Chemical } \\
\text { compounds }\end{array}$ & $\begin{array}{l}\text { Applicable for therapeutic } \\
\text { interventions }\end{array}$ & Potentially high off-target effects \\
\hline
\end{tabular}

